\title{
Constraining global methane emissions and uptake by ecosystems
}

\author{
R. Spahni ${ }^{1,2}$, R. Wania' ${ }^{2,3}$, L. Neef ${ }^{4,5}$, M. van Weele ${ }^{4}$, I. Pison ${ }^{6}$, P. Bousquet ${ }^{6}$, C. Frankenberg ${ }^{7, *}$, P. N. Foster ${ }^{2}$, F. Joos ${ }^{1}$, \\ I. C. Prentice ${ }^{2,8,9}$, and P. van Velthoven ${ }^{4}$ \\ ${ }^{1}$ Climate and Environmental Physics, Physics Institute, and Oeschger Centre for Climate Change Research, \\ University of Bern, Bern, Switzerland \\ ${ }^{2}$ QUEST, Department of Earth Sciences, University of Bristol, Bristol, UK \\ ${ }^{3}$ School of Earth and Ocean Sciences, University of Victoria, Victoria, British Columbia, Canada \\ ${ }^{4}$ KNMI, Royal Netherlands Meteorological Institute, De Bilt, The Netherlands \\ ${ }^{5}$ Earth System modeling, Helmholtz Centre Potsdam, Potsdam, Germany \\ ${ }^{6}$ Laboratoire des Sciences du Climat et de l'Environnement (LSCE), Gif-sur-Yvette, France \\ ${ }^{7}$ Netherlands Institute for Space Research, Utrecht, The Netherlands \\ ${ }^{8}$ Department of Biological Sciences, Macquarie University, North Ryde, NSW 2109, Australia \\ ${ }^{9}$ Grantham Institute and Division of Biology, Imperial College, Ascot SL5 7PY, UK \\ * now at: Jet Propulsion Laboratory, California Institute of Technology, Pasadena, USA
}

Received: 28 October 2010 - Published in Biogeosciences Discuss.: 11 January 2011

Revised: 20 May 2011 - Accepted: 30 May 2011 - Published: 23 June 2011

\begin{abstract}
Natural methane $\left(\mathrm{CH}_{4}\right)$ emissions from wet ecosystems are an important part of today's global $\mathrm{CH}_{4}$ budget. Climate affects the exchange of $\mathrm{CH}_{4}$ between ecosystems and the atmosphere by influencing $\mathrm{CH}_{4}$ production, oxidation, and transport in the soil. The net $\mathrm{CH}_{4}$ exchange depends on ecosystem hydrology, soil and vegetation characteristics. Here, the LPJ-WHyMe global dynamical vegetation model is used to simulate global net $\mathrm{CH}_{4}$ emissions for different ecosystems: northern peatlands $\left(45^{\circ}-90^{\circ} \mathrm{N}\right)$, naturally inundated wetlands $\left(60^{\circ} \mathrm{S}-45^{\circ} \mathrm{N}\right)$, rice agriculture and wet mineral soils. Mineral soils are a potential $\mathrm{CH}_{4}$ sink, but can also be a source with the direction of the net exchange depending on soil moisture content. The geographical and seasonal distributions are evaluated against multi-dimensional atmospheric inversions for 2003-2005, using two independent four-dimensional variational assimilation systems. The atmospheric inversions are constrained by the atmospheric $\mathrm{CH}_{4}$ observations of the SCIAMACHY satellite instrument and global surface networks. Compared to LPJ-WHyMe the inversions result in a significant reduction in the emissions from northern peatlands and suggest that LPJ-WHyMe maximum annual emissions peak about one month late. The
\end{abstract}

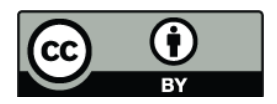

Correspondence to: R. Spahni (spahni@climate.unibe.ch) inversions do not put strong constraints on the division of sources between inundated wetlands and wet mineral soils in the tropics. Based on the inversion results we diagnose model parameters in LPJ-WHyMe and simulate the surface exchange of $\mathrm{CH}_{4}$ over the period 1990-2008. Over the whole period we infer an increase of global ecosystem $\mathrm{CH}_{4}$ emissions of $+1.11 \mathrm{Tg} \mathrm{CH}_{4} \mathrm{yr}^{-1}$, not considering potential additional changes in wetland extent. The increase in simulated $\mathrm{CH}_{4}$ emissions is attributed to enhanced soil respiration resulting from the observed rise in land temperature and in atmospheric carbon dioxide that were used as input. The longterm decline of the atmospheric $\mathrm{CH}_{4}$ growth rate from 1990 to 2006 cannot be fully explained with the simulated ecosystem emissions. However, these emissions show an increasing trend of $+3.62 \mathrm{Tg} \mathrm{CH}_{4} \mathrm{yr}^{-1}$ over 2005-2008 which can partly explain the renewed increase in atmospheric $\mathrm{CH}_{4}$ concentration during recent years.

\section{Introduction}

\subsection{General introduction}

Anthropogenic methane $\left(\mathrm{CH}_{4}\right)$ emissions contribute significantly to global radiative forcing. Since pre-industrial times (ca. $1750 \mathrm{AD}$ ), anthropogenic $\mathrm{CH}_{4}$ emissions have produced

Published by Copernicus Publications on behalf of the European Geosciences Union. 
a current forcing of $0.48 \mathrm{~W} \mathrm{~m}^{-2}$ (Denman et al., 2007). This corresponds to $\sim 30 \%$ of the radiative forcing from $\mathrm{CO}_{2}\left(1.66 \mathrm{~W} \mathrm{~m}^{-2}\right)$. In addition, present-day global natural $\mathrm{CH}_{4}$ emissions are estimated to be $145-260 \mathrm{Tg} \mathrm{yr}^{-1}$ $\left(1 \mathrm{Tg} \mathrm{yr}^{-1}=10^{12} \mathrm{~g} \mathrm{CH}_{4} \mathrm{yr}^{-1}\right)$, which is $\sim 25-50 \%$ of total $\mathrm{CH}_{4}$ emissions ( 503-610 $\mathrm{Tg} \mathrm{yr}^{-1}$ ) (Denman et al., 2007).

The goal of this study is to identify trends and variability of global net $\mathrm{CH}_{4}$ exchange from ecosystems over the last two decades. We also make a first attempt to attribute the variability of $\mathrm{CH}_{4}$ exchange to different categories of ecosystems on the global scale. In the existing literature, biogeochemical processes leading to $\mathrm{CH}_{4}$ exchanges are commonly treated identically as emissions from "wetlands". Here we try to assess these processes individually by modelling the biogeochemical cycle of the land biosphere, the atmospheric chemistry and transport of emitted $\mathrm{CH}_{4}$, and the uncertainties associated with these processes.

\subsection{Uncertainties and variability}

The uncertainty in total natural $\mathrm{CH}_{4}$ emissions is mainly due to lack of knowledge of the geographical distribution and interannual variability of $\mathrm{CH}_{4}$ emissions from ecosystems, the largest natural source (Denman et al., 2007). Inverse ("top-down") modelling of atmospheric $\mathrm{CH}_{4}$ emissions suggests that interannual variability of wet ecosystem emissions is $\pm 12 \mathrm{Tg} \mathrm{yr}^{-1}$, which explains about $70 \%$ of global emission anomalies over the period 1984-2003 (Bousquet et al., 2006). Interannual variability in $\mathrm{CH}_{4}$ loss additionally contributes to the uncertainty of the global $\mathrm{CH}_{4}$ budget and thereby the inferred emissions. In the free troposphere $\mathrm{CH}_{4}$ molecules are photochemically destroyed by reaction with hydroxyl radicals $(\mathrm{OH})$. The tropospheric $\mathrm{OH}$ loss represents the main global $\mathrm{CH}_{4}$ sink $\left(\sim 428-511 \mathrm{Tg} \mathrm{yr}^{-1}\right)$ (Denman et al., 2007). The largest loss and, thus, the shortest $\mathrm{CH}_{4}$ life time is found in the tropical troposphere, where the primary production of $\mathrm{OH}$ radicals from ozone $\left(\mathrm{O}_{3}\right)$ photolysis is most efficient because of the combination of strong ultraviolet radiation intensity and high humidity. Taking into account a stratospheric sink of $\sim 40 \mathrm{Tg} \mathrm{yr}^{-1}$ and $\mathrm{CH}_{4}$ consumption in soils of $\sim 30 \mathrm{Tg} \mathrm{yr}^{-1}$, the present-day global chemical $\mathrm{CH}_{4}$ life time is estimated to be within the range $8.45 \pm 0.38$ yr (Stevenson et al., 2006). The debate on the interannual variability in $\mathrm{OH}-$ loss in recent decades (Forster et al., 2007; Prinn et al., 2005; Montzka et al., 2011) is still unresolved.

Atmospheric $\mathrm{CH}_{4}$ concentration remained roughly stable during the late 1990 s to 2006 . This points to a temporary balance between sources and sinks. Atmospheric $\mathrm{CH}_{4}$ concentrations started to rise again from the year 2007 onward (Rigby et al., 2008; Dlugokencky et al., 2009). The renewed increase seems to reflect growing anthropogenic emissions of $\mathrm{CH}_{4}$ (EC-JRC/PBL, 2009), while the temporary balance does not. The rapid rise in anthropogenic pollution of atmospheric constituents like $\mathrm{NO}_{\mathrm{x}}$, predominantly at (sub-)tropical latitudes, may lead to enhanced ozone formation and therefore higher $\mathrm{OH}$ concentrations that reduce the chemical lifetime of tropospheric $\mathrm{CH}_{4}$ (Dalsøren et al., 2009; van Weele and van Velthoven, 2010).

The period of stabilisation has been explained by decreasing anthropogenic emissions until 1999, followed by a decline in wetland emissions (Bousquet et al., 2006). However, the ecological, biogeochemical, thermal and hydrological processes governing $\mathrm{CH}_{4}$ exchange between ecosystems and the atmosphere are poorly constrained on the global scale. Thus, estimates of global emissions are often calculated using simple parametrisations (e.g., Kaplan, 2002), but process based "bottom-up" emission models have become available in the last decade (e.g., Walter et al., 2001a,b; Kettunen, 2003; Zhuang et al., 2004; Wania et al., 2010a).

\subsection{Approach description}

Here we use the Lund-Potsdam-Jena dynamic global vegetation model (DGVM) with Wetland Hydrology and Methane (LPJ-WHyMe), that includes permafrost dynamics, peatland hydrology and peatland vegetation (Wania et al., 2009a,b), to simulate $\mathrm{CH}_{4}$ emissions from northern peatlands (Wania et al., 2010a). Global model output of LPJ-WHyMe is used to parametrise emissions from inundated wetlands south of $45^{\circ} \mathrm{N}$, rice agriculture and wet mineral soils, and to parametrise $\mathrm{CH}_{4}$ uptake by soils.

We combine this "bottom-up" model approach with two "top-down" atmospheric inversions using the LMDz-SACS (Pison et al., 2009) and TM5-4Dvar (Bergamaschi et al., 2007; Meirink et al., 2008a,b) assimilation frameworks for the years 2003-2005. The inversions are constrained by $\mathrm{CH}_{4}$ concentration observations from the SCIAMACHY satellite instrument (Frankenberg et al., 2008) and by the observations of the global $\mathrm{CH}_{4}$ ground-based networks (GLOBALVIEW$\left.\mathrm{CH}_{4}, 2009\right)$.

In an iterative approach, we separate and test emission distributions that are based on detailed process modelling and parametrisations on a global scale. Net exchange fluxes from LPJ-WHyMe are constrained by their spatial $\left(1^{\circ}\right.$ by $1^{\circ}$ grid $)$ and temporal (monthly) patterns, and their agreement with chemistry, transport and concentrations in the atmosphere. In Sect. 2 we describe the models used for the biogeochemical and the atmospheric inverse modelling. The separation into different source and sink categories based on the involved process schemes is explained in Sect. 3. Emission distributions and climate-induced trends and budgets for the period 1990-2008 are presented in Sect. 4. Finally, the results are discussed (Sect. 5) and summarised (Sect. 6). 


\section{Modelling framework}

\subsection{Biogeochemical process modelling}

For the "bottom-up" biogeochemical process modelling of $\mathrm{CH}_{4}$ emissions we apply LPJ-WHyMe v1.3 (hereafter LPJ) for (i) high-northern-latitude peatlands $\left(45^{\circ}-90^{\circ} \mathrm{N}\right)$ and for (ii) global mineral soils.

(i) In high-northern-latitude peatlands (hereafter northern peatlands), LPJ simulates peatland vegetation (either the peatland specific plant functional types (PFTs) of flood tolerant C3 graminoids, and, Sphagnum mosses or any of the generic PFTs depending on the inundation status), soil temperature (freezing and thawing), permafrost dynamics (active layer depth), peatland hydrology (evapotranspiration, water table position) and snow cover (Wania et al., 2009a). Additionally, LPJ simulates the carbon balance of the peat, thus the soil carbon stock, carbon accumulation and decomposition rates (Wania et al., 2009b). The soil carbon serves as a substrate for methanogenesis parametrised as a fraction of soil heterotrophic respiration (HR). $\mathrm{CH}_{4}$ is transported to the surface by plant mediated transport, by diffusion through the soil or by ebullition. $\mathrm{CH}_{4}$ is oxidised under aerobic conditions in the soil layer and during transport (Wania et al., 2010b).

(ii) On mineral soils, LPJ simulates natural vegetation dynamics of 10 PFTs, soil hydrology (evapotranspiration, soil moisture), soil temperatures (freezing and thawing) and snow cover (Sitch et al., 2003; Gerten et al., 2004; Wania et al., 2009a) using non-peatland hydrology in the model. The use of peatland and non-peatland hydrology depends on the soil class, but can also be switched off completely. LPJ gives estimates for the land carbon pools and soil HR rates depending on temperature and soil moisture content (Wania et al., 2009b). Versions of LPJ have been applied to study the global carbon cycle in the past (e.g., Joos et al., 2004) and the future (e.g., Sitch et al., 2008). $\mathrm{CH}_{4}$ soil fluxes from mineral soils are estimated by using relationships between $\mathrm{CH}_{4}$ emissions and soil $\mathrm{HR}$, soil moisture and temperature simulated by LPJ as described in the next section.

The Climate Research Unit (CRU) TS 3.0 climate data set (Mitchell and Jones, 2005) is used to force LPJ. Monthly input data to LPJ are surface air temperature, total precipitation, fractional sunshine hours from cloud cover percentage, and number of wet days from the CRU climatology. Additionally, the CRUNCEP data set was used to perform simulations for the period 1990-2008 (Viovy and Ciais, 2009, personal communication). The model spin-up procedure and other input data are described in Wania et al. (2009a, 2010a).

\subsection{Inverse atmospheric modelling using four-dimensional data assimilation}

Inversions of trace gas emissions constrained by surface as well as satellite-borne observations are a powerful tool for the validation of emission distributions and their trends and variability. Inversions based in 4D variational data assimilation (4D-Var, Houweling et al., 1999; Meirink et al., 2008a,b; Pison et al., 2009), which use the adjoint of a chemistry transport model to correct fluxes such that the fit between observed and modelled concentration is improved, are especially powerful.

Here we use two 4D-Var inversion systems: TM5-4Dvar (Bergamaschi et al., 2007, 2009; Meirink et al., 2008a,b) and LMDz-SACS (Pison et al., 2009). For the tracer-transport model TM5, the 4D-Var inversion framework optimises $\mathrm{CH}_{4}$ flux per model-grid-box per emission category per month. Therefore, it is used to test in a diagnostic way the biogeochemically modelled $\mathrm{CH}_{4}$ emissions per category by LPJ. This inversion system has no interactive chemistry, with $\mathrm{CH}_{4}$ loss parametrised with a prescribed $\mathrm{OH}$ field (Bergamaschi et al., 2007). In contrast the LMDz-SACS inversion framework simultaneously inverts three chemical species (methane $-\mathrm{CH}_{4}$, carbon monoxid - $\mathrm{CO}$, hydrogen $-\mathrm{H}_{2}$ ) and has interactive chemistry (Pison et al., 2009). While TM5-4Dvar solves for fluxes per category, LMDz-SACS solves for total monthly $\mathrm{CH}_{4}$ flux per model grid-box. The full description of both inversion systems is given in Appendix B.

\section{Methane source and sink categories}

Among the natural sources of $\mathrm{CH}_{4}$ we focus on biogenic soil emissions and subdivide them by type of ecosystem. Many different global classifications categorise potentially $\mathrm{CH}_{4-}$ producing ecosystems by hydrology, geomorphology, salinity, soil composition, vegetation, biogeochemistry, or a combination of these (e.g., Matthews and Fung, 1987; Semeniuk and Semeniuk, 1997). Here we use a classification with respect to the processes relevant for the microbial production, oxidation and transport of $\mathrm{CH}_{4}$ in natural soils. The classification is simplified to three types: peatlands, inundated wetlands (including rice agriculture), and mineral soils. In addition, we simulate $\mathrm{CH}_{4}$ uptake in mineral soils and prescribe anthropogenic emissions from the EDGAR inventory (EC-JRC/PBL, 2009) as well as some smaller natural $\mathrm{CH}_{4}$ sources (Sect. 3.4). In the following Sects. 3.1-3.3 we explain the calculation and parametrisation of sources and sinks in more detail. We test two emission scenarios, $\mathrm{SC} 1$ and $\mathrm{SC} 2$ (summarised in Table 1 and discussed in Sect. 4) for their consistency with the observed $\mathrm{CH}_{4}$ concentrations.

\subsection{Northern peatlands}

Peatlands are important ecosystems in northern high latitudes. Peat is an accumulation of partially decomposed 
Table 1. Differences in model setup and modelled $\mathrm{CH}_{4}$ surface fluxes (global $1^{\circ} \times 1^{\circ}$ grid) between LPJ scenarios SC1 and SC2. Emission changes were achieved by changing source area or source strength in SC2 (column 3 and 4). The area assigned to the category wet mineral soils and their $\mathrm{CH}_{4}$ emissions were considerably reduced in SC2 by raising the threshold of soil moisture (SM), expressed as fraction of the water holding capacity (whc), above which $\mathrm{CH}_{4}$ emissions can occur.

\begin{tabular}{|c|c|c|c|}
\hline Categories & $\mathrm{SC} 1$ & $\mathrm{SC} 2$ & Emission change \\
\hline \multicolumn{4}{|l|}{ Northern peatlands } \\
\hline Area $\left(45^{\circ}-90^{\circ} \mathrm{N}\right)$ : & $\begin{array}{l}\text { organic soil } \\
\text { carbon map }\end{array}$ & unchanged & - \\
\hline$r_{\mathrm{C}\left[\mathrm{CH}_{4}\right] / \mathrm{C}\left[\mathrm{CO}_{2}\right]:}$ & $25.0 \%$ & $20.0 \%$ & northern extra-tropical decrease \\
\hline $\begin{array}{l}\text { Inundated wetlands } \\
\text { area }\left(60^{\circ} \mathrm{S}-45^{\circ} \mathrm{N}\right) \text { : }\end{array}$ & $\begin{array}{l}\text { inundation } \\
\text { map }\end{array}$ & unchanged & - \\
\hline$r_{\mathrm{C}\left[\mathrm{CH}_{4}\right] / \mathrm{C}\left[\mathrm{CO}_{2}\right]}:$ & $2.40 \% *$ & $4.15 \% *$ & (sub-)tropical increase \\
\hline $\begin{array}{l}\text { Rice agriculture } \\
\text { area (global): }\end{array}$ & $\begin{array}{l}\text { rice fraction } \\
\text { map }\end{array}$ & unchanged & - \\
\hline$r_{\mathrm{C}\left[\mathrm{CH}_{4}\right] / \mathrm{C}\left[\mathrm{CO}_{2}\right]}:$ & $2.40 \% *$ & $4.15 \% *$ & sub-tropical increase \\
\hline $\begin{array}{l}\text { Wet mineral soils } \\
\text { area (global): }\end{array}$ & $\begin{array}{l}\mathrm{SM}> \\
85 \% \text { whc }\end{array}$ & $\begin{array}{l}\mathrm{SM}> \\
95 \% \text { whc }\end{array}$ & $\begin{array}{l}\text { northern extra-tropical decrease } \\
\text { and small tropical decrease }\end{array}$ \\
\hline$r_{\mathrm{C}\left[\mathrm{CH}_{4}\right] / \mathrm{C}\left[\mathrm{CO}_{2}\right]}:$ & $0.52 \% *$ & unchanged & - \\
\hline $\begin{array}{l}\text { Soil uptake } \\
\text { area (global): }\end{array}$ & $\begin{array}{l}\text { defined as in } \\
\text { Curry (2007) }\end{array}$ & unchanged & - \\
\hline
\end{tabular}

${ }^{*}$ Here, the carbon conversion factor also includes oxidation of $\mathrm{CH}_{4}$ to $\mathrm{CO}_{2}$ during transport to the surface and general flux tuning.

organic matter. Peat layer growth and decomposition depend principally on its composition and the water table position, and to a lesser extent also on soil temperature (Rouse et al., 1997). Peatland formation in the arctic, boreal and alpine regions is spatially and temporally influenced by the occurrence of permafrost (Robinson and Moore, 2000). LPJ directly simulates these physical processes and in addition, $\mathrm{CH}_{4}$ production, oxidation and transport to the atmosphere (Wania et al., 2010b). The production term is calculated proportional to HR in the soil, where HR depends on the mass $\left(M_{i}\right)$ of each individual LPJ carbon pool (CP) in $\mathrm{gC}$ and the associated turnover rate $k_{i}\left(\mathrm{yr}^{-1}\right)$ :

$\mathrm{HR}=\sum_{i \in \mathrm{CP}} k_{i} \cdot M_{i}=\sum_{i \in \mathrm{CP}} k_{i}^{10} \cdot R_{\mathrm{T}} \cdot R_{\text {moist }} \cdot M_{i}$

Turnover rates $\left(k_{i}^{10}\right)$ at $10^{\circ} \mathrm{C}$ for the exudates, aboveground and below-ground litter carbon pools, and fast and slow soil carbon pools are given in (Wania et al., 2010b). The turnover rates increase with temperature $\left(R_{\mathrm{T}}\right)$ (Lloyd and Taylor, 1994) and have normalised exponential dependency with soil water content ( $R_{\text {moist }}$ ) (Fang and Moncrieff, 1999) for mineral soils. For peatlands $R_{\text {moist }}$ is set to a constant of 0.35 (Wania et al., 2010a). $\mathrm{CH}_{4}$ emissions are sensitive to the carbon ratio of $\mathrm{CH}_{4}$ to $\mathrm{CO}_{2}$ production $\left(r_{\left.\left.\mathrm{C}_{[} \mathrm{CH}_{4}\right] / \mathrm{C}_{[} \mathrm{CO}_{2}\right]}\right)$, which is applied to anoxic conditions but weighted by the volumetric fraction of air if a layer is not completely anoxic (Wania et al., 2010b). Due to some uncertainty of this value, we test two different values for $r_{\left.\mathrm{C}\left[\mathrm{CH}_{4}\right] / \mathrm{C}_{\mathrm{CO}}\right]}$ based on comparisons with site data, namely $25 \%$ (SC1) and $20 \%$ (SC2) (Wania et al., 2010a). The latter resulting in a lower methane production in peatlands. In our classification peatlands include bogs, fens and mires, and are found predominantly in the Northern Hemisphere with an estimated maximum area of 2.99-3.20 $\times 10^{6} \mathrm{~km}^{-2}$ (Matthews and Fung, 1987; Aselmann and Crutzen, 1989). As detailed in Sect. 6 of Wania et al. (2010a) and Sect. 3 of Wania et al. (2009a), we calculate the fractional peatland cover for the circumpolar region $\left(45^{\circ}-90^{\circ} \mathrm{N}\right)$ from organic soil carbon content derived from the IGBP-DIS $5^{\prime} \times 5^{\prime}$ resolution map (Global Soil Data Task Group, 2000). The assumption in this approach is that high organic soil carbon content indicates areas where peat has been or currently is accumulating. After a comparison with the wetland area derived from a multiple satellite approach (Prigent et al., 2007) the peatland fractions derived from the IGBP-DIS data were further downscaled by a factor of 0.38 (Wania et al., 2010a). The resulting fractional peatland area 


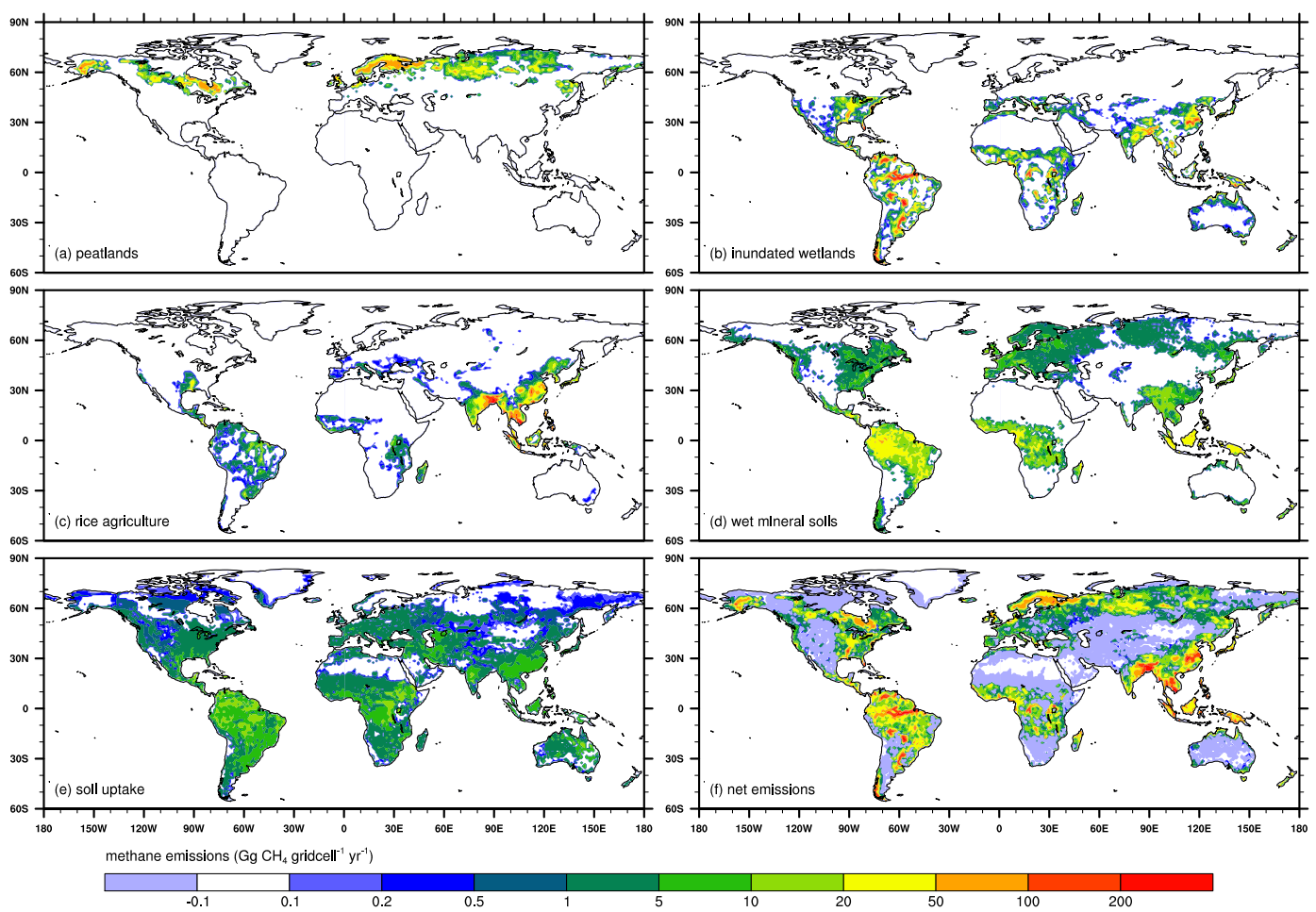

Fig. 1. $\mathrm{CH}_{4}$ exchange by categories as simulated with LPJ for 2004 on a global grid $\left(1^{\circ} \times 1^{\circ}\right)$ and with the settings of SC2: (a) Northern extra-tropical peatlands based on a soil organic carbon map (Wania et al., 2010a), (b) inundated wetlands based on an inundation fraction map (Prigent et al., 2007), (c) rice agriculture based on a rice fraction map (Leff et al., 2004), (d) global wet mineral soils estimated using a threshold for soil moisture content in LPJ, (e) global soil uptake fluxes based on atmospheric surface concentrations (GLOBALVIEW-CH , $_{4}$ 2009) and the scheme by Curry (2007), and (f) net emissions from LPJ computed from the sum of all sources (a-d) minus soil uptake (e). Note the non-linear color scale in (a-f) and areas with negative numbers in (f), indicating an annual net $\mathrm{CH}_{4}$ uptake.

( $\left.f_{\text {peat }}\right)$ between $45^{\circ}$ and $90^{\circ} \mathrm{N}$ is about $2.05 \times 10^{6} \mathrm{~km}^{-2}$. In addition, flux strengths are multiplied by a factor of 0.75 to take account of the micro-topographic heterogeneity found in peatlands (Wania et al., 2010a). Total peatland emissions for the circumpolar region are $51.1 \mathrm{Tg} \mathrm{CH}_{4}$ (SC1) and $38.5 \mathrm{Tg} \mathrm{CH}_{4}$ (SC2) for the year 2004 (Fig. 1a).

Tropical peatlands cover an area of $\sim 0.42 \times 10^{6} \mathrm{~km}^{-2}$, predominantly in South East (SE) Asia (Page et al., 2004). Thus, they represent $\sim 10-15 \%$ of global peatland area. Tropical and boreal peatlands are, due to their climate regime, rather contrasting ecosystems in terms of hydrology, peat accumulation rate and inventory, and presumably sensitivities in $\mathrm{CH}_{4}$ emissions. Thus, we treat tropical peatlands separately from boreal peatlands: tropical peatlands are included in the class of inundated wetlands as described in the next section.

\subsection{Naturally inundated wetlands and rice agriculture}

Naturally inundated wetlands $\left(60^{\circ} \mathrm{S}\right.$ to $\left.45^{\circ} \mathrm{N}\right)$ are permanently flooded areas with a water table position close to the soil surface during the period of inundation. This category includes forest and non-forest swamps, marshes, peatlands and open water bodies in temporal, subtropical and tropical regions. We use the inundation fraction data $\left(0.25^{\circ} \times 0.25^{\circ}\right.$ resolution) from a multi-satellite method (Prigent et al., 2007), and calculate the monthly mean fractional inundation on the global $1^{\circ} \times 1^{\circ}$ grid. A similar approach has recently been conducted for a global single wetland type source (Ringeval et al., 2010). The monthly fractional inundation data are available for the period 1993-2000. In this study we use the time-average mean fractional inundation for each month. In a sensitivity simulation, described in Sect. 4.3, the temporally varying data are prescribed for the period 1993 2000 only.

Since satellite observations map all flooded areas, both naturally inundated and irrigated wetlands (i.e. fractional cover of rice agriculture) are included in the data set (Prigent et al., 2007). To separate naturally inundated wetlands from rice agriculture, we concatenate fractional inundation data with a map of fractional rice cover (Leff et al., 2004). Rice agricultural areas are concentrated in SE Asia and are an important net source of atmospheric $\mathrm{CH}_{4}$ of $31-112 \mathrm{Tg} \mathrm{CH}_{4}$ (Denman et al., 2007). However, more recent estimates point to somewhat lower emissions of 14.8 to $41.7 \mathrm{Tg} \mathrm{CH}_{4}$ from rice agriculture (Yan et al., 2009). The fractional rice cover as given by Leff et al. (2004) is considered as an 
annual maximum extent $\left(f_{\text {ricemax }}\right)$. To get the monthly rice extent $\left(f_{\text {rice }}\right)$, we truncate the fractional rice cover to the fractional inundation $\left(f_{\text {inund }}\right)$ for each $1^{\circ} \times 1^{\circ}$ grid cell $(i)$ and each month $(m)$. The remaining fractional area is then assumed to represent the fractional cover of naturally inundated wetlands $\left(f_{\text {natwet }}\right)$ :

$f_{\text {rice }, i, m}=\min \left(f_{\text {inund }, i, m}, f_{\text {ricemax }, i, m}\right)$

$f_{\text {natwet }, i, m}=f_{\text {inund }, i, m}-f_{\text {rice }, i, m}$

With this separation it is possible to discriminate between $\mathrm{CH}_{4}$ emissions from naturally inundated wetlands and irrigated rice agriculture. $\mathrm{LPJ}$ does not simulate $\mathrm{CH}_{4}$ emissions in a process-based way for temperate, sub-tropical and tropical ecosystems. Nevertheless, LPJ dynamically simulates natural vegetation distribution (trees and grass), gross and net primary productivity, soil HR and related carbon pools (Sitch et al., 2003). Assuming that these natural soils develop anoxic conditions when being flooded, we expect that a fraction of carbon, respired in the soil, is released as $\mathrm{CH}_{4}$ instead of as $\mathrm{CO}_{2}$ for the period of inundation. For $\mathrm{CH}_{4}$ emissions from naturally inundated wetlands and rice agriculture we directly modify the carbon conversion ratio $r_{\left.\mathrm{C}\left[\mathrm{CH}_{4}\right] / \mathrm{C}_{[} \mathrm{CO}_{2}\right]}$ to include $\mathrm{CH}_{4}$ oxidation, transport and general flux tuning. The modified ratio is thus lower than for peatland emissions, and set to $2.40 \%$ (SC1) and $4.15 \%$ (SC2) (see Appendix A) in agreement with previous estimates (Christensen et al., 1996). $\mathrm{CH}_{4}$ emissions ( $\left.e_{\text {inund }}\right)$ per $\mathrm{m}^{2}$ and month $(m)$ in grid cell $i$ are then derived from soil HR as

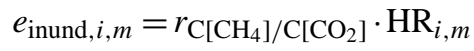

$E_{\text {natwet }, i, m}=e_{\text {inund }, i, m} \cdot f_{\text {natwet }, i, m} \cdot A_{i}$

$E_{\text {rice }, i, m}=e_{\text {inund }, i, m} \cdot f_{\text {rice }, i, m} \cdot A_{i}$

where $E_{\text {natwet }}$ and $E_{\text {rice }}$ are total emissions from naturally inundated wetlands and rice agriculture, respectively, per grid cell with the area $A_{i}$ (in $\mathrm{m}^{2}$ ). The global parametrisation can be checked against regional emission inventories for rice agriculture in SE Asia (Fig. 2). The parametrised fluxes agree well with emission distributions and total estimates from the EDGAR data base (EC-JRC/PBL, 2009) with the exception that emissions in North-Western India along the Himalayan foothills are missing; this is due to a geographical mismatch of fractional rice cover (Leff et al., 2004) and precipitation input data, with low precipitation in the CRU input data preventing vegetation growth and $\mathrm{CH}_{4}$ production in LPJ in the Indo-Gangetic Plain.

In summary, we simplify the classification of global wet ecosystems by latitude to prevent double counting of areas and emissions. Wetlands north of $45^{\circ} \mathrm{N}$ are considered to be peatlands $\left(f_{\text {natwet }}=0\right)$, whereas wetlands south of $45^{\circ} \mathrm{N}$ are classified as inundated wetlands $\left(f_{\text {peat }}=0\right)$. The reason for the $45^{\circ} \mathrm{N}$ cut-off line is that LPJ-WHyMe was specifically
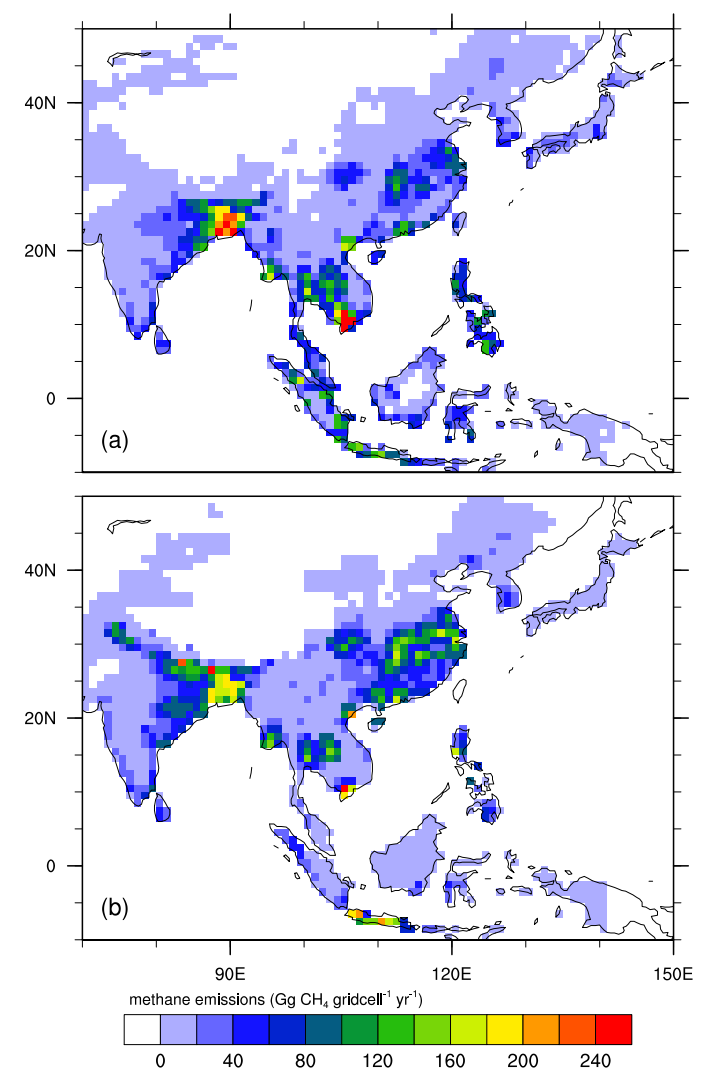

Fig. 2. Methane emissions in $\mathrm{Gg} \mathrm{CH}_{4}$ from rice fields in SE Asia for the year 2000. (a) Emissions are estimated from the gridded distribution of fractional inundation (Prigent et al., 2007) and fractional rice cover (Leff et al., 2004) and assuming that $4.15 \%$ of the heterotrophic respiration simulated by LPJ is converted to methane in inundated rice fields (scenario SC2). (b) Emissions from the EDGAR data (EC-JRC/PBL, 2009). Total emissions in SE Asia from rice cultivation are 36.4 and $36.6 \mathrm{Tg} \mathrm{CH}_{4}$ from $\mathrm{LPJ}$ and EDGAR, respectively. Resolution for both maps is $1^{\circ} \times 1^{\circ}$.

developed for methane emissions from peatlands in cold areas (either high latitude or high altitude), of which the majority is found north of $45^{\circ} \mathrm{N}$. Since LPJ-WHyMe has not been tested yet for wetlands other than this kind of peatland, we chose to use the $45^{\circ} \mathrm{N}$ cut-off as a boundary between simulating $\mathrm{CH}_{4}$ emissions within LPJ-WHyMe for northern peatlands and using a more generic correlation approach (Eqs. 46) for the rest of the inundated areas. Additionally, seasonal rice agriculture is calculated from global fractional inundation and global rice cover extent. The global distribution of these three sources are shown in Fig. 1a-c as fluxes per grid cell and additionally in Fig. A1a-c as fluxes per unit area.

Mineral soils that are not inundated can still be a net $\mathrm{CH}_{4}$ source. Soils with a low soil moisture content imply oxic conditions which allow bacteria to consume $\mathrm{CH}_{4}$ (Curry, 2007, and refs. therein). Relatively high soil moisture content however limits the availability of oxygen, a situation which enables methanogenic archaea to produce $\mathrm{CH}_{4}$ and 
suppresses $\mathrm{CH}_{4}$ consumption. Above a certain soil moisture threshold, a part of $\mathrm{CH}_{4}$ generated within the soil can diffuse through the soil layer into the atmosphere without being oxidised. This has been observed during field experiments in different soil-vegetation systems (see references in Table A). Therefore, we propose an additional global source of $\mathrm{CH}_{4}$ from wet mineral soils. We test two soil moisture thresholds above which $\mathrm{CH}_{4}$ emissions can occur: $85 \%$ (SC1) and $95 \%$ (SC2) of water holding capacity (whc). These thresholds correspond to a fraction of 0.28 to 0.49 (SC1) and 0.31 to 0.55 (SC2) of water filled pore space $\left(\mathrm{WFP}_{\text {th }}\right)$, depending on soil type, field capacity, permanent wilting point and porosity. In savannas, a switch from methane sink to methane source was

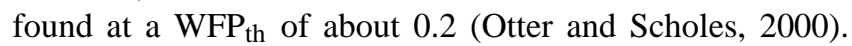
The $\mathrm{WFP}_{\text {th }}$ is fulfilled in LPJ for large areas in the boreal and tropical region in $\mathrm{SC} 1$ and predominantly in the tropics in SC2 (Fig. 1d). The additional source could thus contribute to the high $\mathrm{CH}_{4}$ emissions in the tropics as inferred from satellite data (Frankenberg et al., 2008). The fractional area for wet mineral soils ( $\left.f_{\text {wetsoil }}\right)$ is given by:

$$
f_{\text {wetsoil }, i, m}=1-f_{\text {peat }, i, m}-f_{\text {natwet }, i, m}-f_{\text {rice }, i, m}
$$

For each grid cell $i$ and month $m$ with soil moisture above the threshold the fraction of wet mineral soil is determined by subtracting the fraction of peatland, inundated wetland and rice agriculture to prevent double counting of emission areas. $f_{\text {wetsoil }}$ is set to zero when soil moisture is below the threshold. Net exchange in wet mineral soils is calculated similarly as for inundated wetlands. But since the oxidation in the partially oxic soils is higher than in inundated soils, we set the carbon conversion ratio $r_{\left.\mathrm{C}\left[\mathrm{CH}_{4}\right] / \mathrm{C}_{[} \mathrm{CO}_{2}\right]}$ to a value of $0.52 \%$ (see Appendix A). The $\mathrm{CH}_{4}$ emission rates per unit area $\left(e_{\text {wetsoil }}\right)$ and total emissions per grid cell $\left(E_{\text {wetsoil }}\right)$ from wet mineral soils are calculated by:

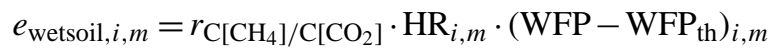

$E_{\text {wetsoil }, i, m}=e_{\text {wetsoil }, i, m} \cdot f_{\text {wetsoil }, i, m} \cdot A_{i}$

where emissions scale with the difference of the actual fraction of water filled pore space (WFP) to the threshold fraction $\left(\mathrm{WFP}_{\text {th }}\right.$ ). Maximum annual $\mathrm{CH}_{4}$ emission rates range from $\sim 1 \mathrm{~g} \mathrm{CH}_{4} \mathrm{~m}^{-2} \mathrm{yr}^{-1}$ in Europe, North America, Africa and SE Asia in agreement with field studies (e.g., Yan et al., 2008) to $\sim 5 \mathrm{~g} \mathrm{CH}_{4} \mathrm{~m}^{-2} \mathrm{yr}^{-1}$ in Northern South America and Indonesia. Thus, $\mathrm{CH}_{4}$ emission rates per $\mathrm{m}^{2}$ and year are at least an order of magnitude smaller than in naturally inundated wetlands or peatlands (Fig. A1). Nevertheless, the large areas of wet mineral soils sum up to a globally significant source with total annual emissions of $93.0 \mathrm{Tg} \mathrm{CH}_{4} \mathrm{yr}^{-1}$ (SC1) and 57.8 $\mathrm{Tg} \mathrm{CH}_{4} \mathrm{yr}^{-1}$ (SC2) in 2004 (Fig. 1d).

\subsection{Soil uptake}

Atmospheric $\mathrm{CH}_{4}$ is biologically consumed in near-surface soils. Global soils account for $28 \mathrm{Tg} \mathrm{CH}_{4} \mathrm{yr}^{-1}$, or $\sim 5 \%$ of the total $\mathrm{CH}_{4}$ sink, whith an uncertainty range of 9$47 \mathrm{Tg} \mathrm{CH}_{4} \mathrm{yr}^{-1}$ (Curry, 2007). The soil consumption of $\mathrm{CH}_{4}$ occurs via oxidation by aerobic bacteria, or methanotrophs, within $3-15 \mathrm{~cm}$ soil depth. The $\mathrm{CH}_{4}$ consumption is determined by the microbial oxidation rate within the soil and the transport of atmospheric $\mathrm{CH}_{4}$ into the soil. The two processes themselves depend most importantly on soil moisture, but also on soil temperature and soil texture. Here we use the uptake scheme of Curry (2007) applied to LPJ output that allows for a monthly estimate of the global $\mathrm{CH}_{4}$ soil sink. In this scheme the $\mathrm{CH}_{4}$ uptake is parametrised for grid cell $i$ and month $m$ as

$J_{i, m}=g_{0} \cdot C_{0, i, m} \cdot r_{\mathrm{cult}, i, m} \cdot r_{\mathrm{w}, i, m} \cdot\left(D_{\mathrm{soil}, i, m} \cdot k_{i, m}\right)^{1 / 2}$

where $g_{0}=586.7 \mathrm{mg} \mathrm{CH}_{4} \mathrm{ppmv}^{-1} \mathrm{~s} \mathrm{~d}^{-1} \mathrm{~m}^{-2} \mathrm{~cm}^{-1}$ is a constant factor that converts the surface concentrations $C_{0}$ expressed in parts per million by volume (ppmv) into an uptake flux $J\left(\mathrm{mg} \mathrm{CH}_{4} \mathrm{~m}^{-2} \mathrm{~d}^{-1}\right)$ (Curry, 2007). We do not account for inhibition of $\mathrm{CH}_{4}$ uptake in cultivated lands and thus leave this factor constant at $r_{\text {cult }, i, m}=1$. However, we do scale $\mathrm{CH}_{4}$ uptake by the fractional area not covered by peatlands, naturally inundated wetlands and rice agriculture with

$r_{\mathrm{w}, i, m}=1-f_{\text {peat }, i, m}-f_{\text {natwet }, i, m}-f_{\text {rice }, i, m}$

This means that $\mathrm{CH}_{4}$ uptake and $\mathrm{CH}_{4}$ emissions from wet mineral soils share the same fractional grid cell area. But resulting fluxes are mutually exclusive through the level of soil moisture, which is a key variable in the parametrisation of the $\mathrm{CH}_{4}$ effective soil diffusion $\left(D_{\text {soil }}\right.$ in $\left.\mathrm{cm}^{2} \mathrm{~s}^{-1}\right)$ and the $\mathrm{CH}_{4}$ oxidation rate $\left(k\right.$ in s $\left.^{-1}\right)$ as calibrated by Curry (2007). As an input for the parametrisation we use soil moisture and soil temperature directly calculated in LPJ at $10 \mathrm{~cm}$ soil depth. Annual fluxes multiplied with grid cell area are shown in Fig. 1e and fluxes per unit area are shown in Fig. A1e. The total global soil uptake for 2004 is $38.1 \mathrm{Tg} \mathrm{CH}_{4}$, which is within the range of previous estimates (Curry, 2007; Ridgwell et al., 1999).

\subsection{Other sources and sinks}

In order to close the global $\mathrm{CH}_{4}$ budget, we prescribe additional $\mathrm{CH}_{4}$ sources. Included are emissions from coal mining, oil and gas production and transport, ruminants, biomass burning (includes natural source), and waste deposits, as given in the EDGAR emission data base (ECJRC/PBL, 2009). Additionally, we prescribe small natural sources of oceanic (Lambert and Schmidt, 1993) and geologic (Etiope et al., 2008; Neef et al., 2010) origin, as well as emissions from termites (Sanderson, 1996). We used the same ocean/geological emission distribution as in Bergamaschi et al. (2007). The tropospheric and stratospheric $\mathrm{CH}_{4}$ sinks are either prescribed or directly calculated within the atmospheric chemistry transport models. The global total of 
Table 2. Total global $\mathrm{CH}_{4}$ sources and sinks in 2004 (in $\mathrm{TgCH}_{4} \mathrm{yr}^{-1}$ ) simulated with LPJ for scenarios SC1 and SC2. Other sources include anthropogenic emissions (EC-JRC/PBL, 2009), oceanic and geologic emissions (Lambert and Schmidt, 1993; Etiope et al., 2008; Neef et al., 2010) and emissions from termites (Sanderson, 1996).

\begin{tabular}{lrr}
\hline Category & SC1 & SC2 \\
\hline modelled sources & & \\
$\quad$ Northern peatlands & 51.4 & 38.6 \\
Inundated wetlands & 43.9 & 75.2 \\
Rice agriculture & 24.8 & 42.6 \\
Wet mineral soils & 92.9 & 57.7 \\
\hline modelled sink & & \\
$\quad$ Soil uptake & -38.9 & -38.9 \\
\hline other sources & & \\
$\quad$ Total & 319.4 & 319.4 \\
\hline Net source & 493.6 & 494.6 \\
\hline
\end{tabular}

other sources is $319 \mathrm{Tg} \mathrm{yr}^{-1}$ for the year 2004 for both scenarios (Table 2).

We did not include aerobic $\mathrm{CH}_{4}$ emissions from plants (Keppler et al., 2006) in our study as they are likely to contribute only $0.2-1.0 \mathrm{Tg} \mathrm{CH}_{4} \mathrm{yr}^{-1}$ to the global $\mathrm{CH}_{4}$ budget (Bloom et al. (2010) and reply to comment by F. Keppler in Spahni et al., 2011). After the completion of our simulations, another new source of $\mathrm{CH}_{4}$ emissions was found, namely emissions from tank bromeliads in the canopy of tropical montane forests (Martinson et al., 2010), who estimated that about $1.2 \mathrm{Tg} \mathrm{CH}_{4} \mathrm{yr}^{-1}$ are emitted from this source. In our opinion, this small source would have had no significant impact on the outcome of our study. We would like to note that what is claimed to be a new source of $\mathrm{CH}_{4}$ emissions by Gauci et al. (2010) and Rice et al. (2010), is in fact implicitly included in our modelling approach of "naturally inundated wetlands" and "wet mineral soils". Our modelling approach, as others before (e.g. Christensen et al., 1996) relate $\mathrm{CH}_{4}$ fluxes to heterotrophic respiration and soil moisture without assuming any specific transport pathway; $\mathrm{CH}_{4}$ may escape via diffusion, ebullition or plant-mediated transport. Therefore, we did not omit this potentially large source of $\mathrm{CH}_{4}$ emissions.

\section{Results}

Results of this study are twofold. First, we highlight the results of the biogeochemical modelling of natural net $\mathrm{CH}_{4}$ exchange using the LPJ dynamical global vegetation model. Second, we incorporate the natural net emissions together with estimates of anthropogenic emissions as prior fluxes into the atmospheric inversion systems TM5-4Dvar and
LMDz-SACS. The inversions provide corrections to the prior fluxes in time (both), space (both), and by category (TM54 Dvar only). These corrections in turn help to validate and interpret the biogeochemical process model and constrain the two emission scenarios.

\subsection{Biogeochemical process modelling}

$\mathrm{CH}_{4}$ emission strength as modelled by LPJ depends directly

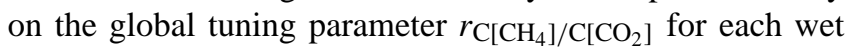
ecosystem type. While the soil HR is influenced by climate and vegetation dynamics, $r_{\left.\mathrm{C}\left[\mathrm{CH}_{4}\right] / \mathrm{C}_{[} \mathrm{CO}_{2}\right]}$ is assumed to be constant over time and space. Setting $\left.r_{\mathrm{C}_{[}} \mathrm{CH}_{4}\right] / \mathrm{C}_{\left[\mathrm{CO}_{2}\right]}$ for the source types of peatlands, naturally inundated wetlands, rice agriculture and wet mineral soils, not only scales the $\mathrm{CH}_{4}$ fluxes per $\mathrm{m}^{2}$, but also impacts the latitudinal distribution and global total of natural $\mathrm{CH}_{4}$ emissions. Since the attribution to different source types is quite ambiguous on a global scale, we propose two scenarios that satisfy regional averages of local flux rates and the global $\mathrm{CH}_{4}$ budget (Appendix A). These two criteria put a constraint on the parameters $r_{\left.\left.\mathrm{C}_{[} \mathrm{CH}_{4}\right] / \mathrm{C}_{[} \mathrm{CO}_{2}\right]}$ for $\mathrm{SC} 1$ and $\mathrm{SC} 2$, which are given in Table 1 and lead to global fluxes as given in Table 2. SC1 is a scenario with large emissions from boreal peatlands and wet mineral soils. Emissions from naturally inundated wetlands and rice agriculture are comparatively small. Northern peatland $\mathrm{CH}_{4}$ emissions are calculated directly from an initial version of Wania et al. (2010a). Soil uptake is calculated directly from LPJ model output and the uptake scheme by (Curry, 2007). In SC2 emissions are dominated by naturally inundated wetlands $(+70 \%$ compared to $\mathrm{SC} 1)$ and rice agriculture $(+70 \%)$ in the tropics and sub-tropics (Fig. 3). Peatland emissions $(-25 \%)$ and wet mineral soil emissions $(-38 \%)$ are substantially reduced in SC2. As a consequence the two scenarios mainly differ in latitudinal gradient of emissions and hence gradient of atmospheric concentration, but not as much in the seasonal cycle.

Highest net $\mathrm{CH}_{4}$ exchange is simulated in the tropics (SE Asia, Central Africa, South America) and the boreal regions (Siberia, Scandinavia, Eastern Canada, Alaska) as shown in Fig. 3. Beside these high-emission regions, the model suggests large areas, where $\mathrm{CH}_{4}$ is emitted at a much smaller rate (Fig. A1), predominantly at low latitudes. Figure 4a highlights the seasonality of emissions for different latitudinal bands. Highest net exchange on a global scale occurs from July until September, consistent with other studies (e.g., Chen and Prinn, 2006). The largest seasonal amplitudes are simulated within the tropical bands of $-30^{\circ}$ to $0^{\circ}$ and $0^{\circ}$ to $30^{\circ} \mathrm{N}$. For these bands the emissions start increasing in spring of each hemisphere. The total tropical emissions are largest for northern summer showing the dominance of the higher percentage of land area in the northern tropics. For the bands further north, the seasons start later, are shorter and contribute less to the global amplitude. This finding very much depends on the distribution of source areas that 


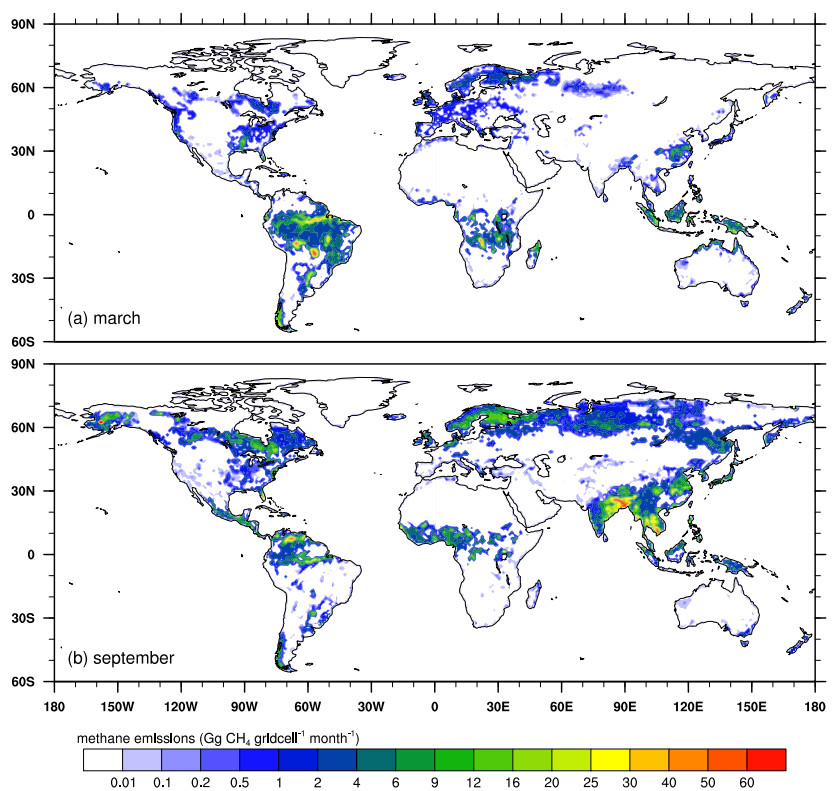

Fig. 3. Net $\mathrm{CH}_{4}$ emissions at $1^{\circ} \times 1^{\circ}$ resolution during (a) March and (b) September 2004 in $\mathrm{GgCH}_{4}$ per grid cell and month for $\mathrm{SC} 2$. Net $\mathrm{CH}_{4}$ emissions are calculated as the sum of northern peatlands, inundated wetlands, rice agriculture and wet mineral soil emissions minus soil uptake weighted by their grid cell fraction and area. Total global emissions from these sources and sinks in 2004 are $175.2 \mathrm{Tg} \mathrm{CH}_{4}$.

are used in the calculation of total fluxes. As mentioned in Sect. 3, these areas are based on the organic soil carbon map for peatlands, the satellite data of inundated areas for naturally inundated wetlands and simulated soil moisture for wet mineral soil emissions and soil uptake. The impact of these distributions of both scenarios are shown in the bottom plot of Fig. 4b. Highest fluxes with $\sim 7 \mathrm{TgCH}_{4} \mathrm{yr}^{-1}$ per degree latitude are found around the Equator. High fluxes over a broader latitudinal range are also found over the sub-tropics and the northern high latitudes. Both distributions modelled by LPJ are very similar to the latitudinal distribution jointly estimated from SCIAMACHY CH $\mathrm{CH}_{4}$ concentrations and gravity space borne data by Bloom et al. (2010). The latitudinal distribution of simulated $\mathrm{CH}_{4}$ fluxes (Fig. 4b) shows only small year-to-year variability, which is understandable since in this study emissions from peatland and inundated wetland areas only vary seasonally and not interannually. It has been shown that both emissions per $\mathrm{m}^{2}$ and emission areas may vary independently, and total $\mathrm{CH}_{4}$ emission variability in space and time is regulated by both (Ringeval et al., 2010).

A remarkable deviation from the latitudinal distrubtion estimated by Bloom et al. (2010) is found at high latitudes, where LPJ emissions peak between $50-60^{\circ} \mathrm{N}$ and $60-70^{\circ} \mathrm{N}$; the latter peak can not be constrained by the SCIAMACHY observations due to the instrument's limited viewing geometry. Large peatland areas existing north of $60^{\circ} \mathrm{N}$ in Alaska, Scandinavia and the Western Siberian Lowlands (WSL alone
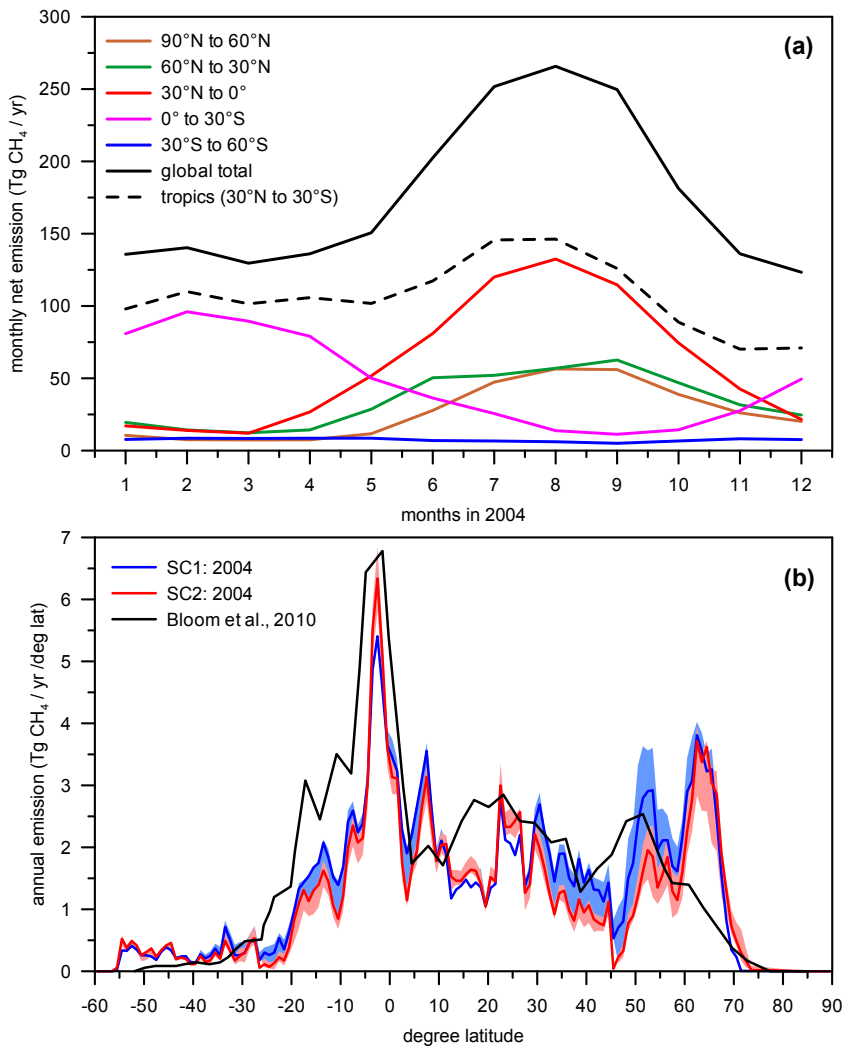

Fig. 4. (a) Zonally integrated monthly net $\mathrm{CH}_{4}$ emissions of 6 latitudinal bands and the global total for SC2 in the year 2004. Net $\mathrm{CH}_{4}$ emissions are calculated as the sum of northern peatlands, inundated wetlands, rice agriculture, and wet mineral soil emissions minus soil uptake weighted by their grid cell fraction and area. (b) Latitudinal distribution of annual net $\mathrm{CH}_{4}$ emissions for SC1 and SC2 in 2004, in comparison with methane emissions estimated from methane and gravity spaceborne data for the 2003-2005 average (Bloom et al., 2010). The colour shaded areas represent the $2 \sigma$ band of the interannual variability over the last two decades for the corresponding scenario.

is $\sim 592440 \mathrm{~km}^{-2}$; Sheng et al., 2004) seem to contribute to high latitude $\mathrm{CH}_{4}$ emissions in LPJ. The atmospheric inversions presented in the next section show that these highlatitude peatland emissions are not in disagreement with atmospheric $\mathrm{CH}_{4}$ concentration data, though the inversions suggest a reduction in their overall size.

\subsection{Atmospheric inversion modelling}

We apply the LMDz-SACS and TM5-4Dvar atmospheric inversion systems constrained by the observed atmospheric $\mathrm{CH}_{4}$ concentrations over the years 2003-2005 with an emphasis on the analysis for the year 2004. Since only the TM54DVar system optimises $\mathrm{CH}_{4}$ fluxes by individual source types, we use this system first to evaluate the two emission scenarios SC1 and SC2 (simulated by LPJ for the year 2004) against the observations. The prior differences between the 


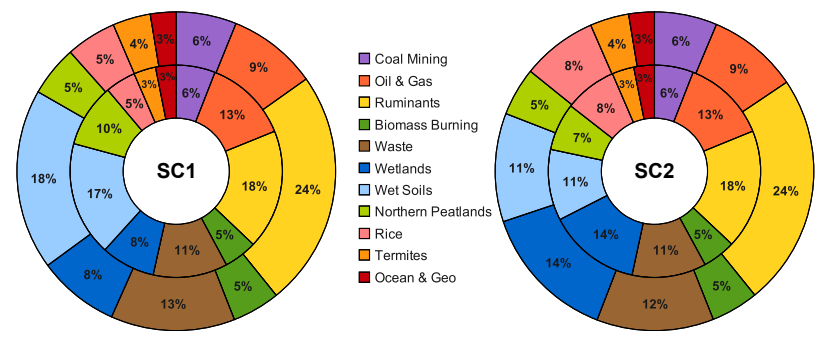

Fig. 5. Global $\mathrm{CH}_{4}$ budget prior (inner circles) and posterior (outer circles) optimisation by the atmospheric concentration inversion using TM5-4Dvar. Emissions by category are given as rounded percentages of total emissions for SC1 and SC2 in the year 2004. The optimisation increased total gross emissions from 533 to $574 \mathrm{Tg} \mathrm{CH}_{4} \mathrm{yr}^{-1}$. Global sinks are not included in the diagrams.

two scenarios, in terms of individual sources and sinks, are outlined in Table 1. The prior and posterior (optimised) relative contributions per source type are shown in Fig. 5 for both scenarios. During the optimisation global gross emissions increase from 533 to $574 \mathrm{Tg} \mathrm{CH}_{4} \mathrm{yr}^{-1}$, and the relative source contributions change as well.

In Fig. 5 it can be seen that the relative strength of anthropogenic ( $\sim 55 \%$; coal mining, oil \& gas, ruminants, biomass burning, waste and rice) to natural emissions ( $\sim 5 \%$; inundated wetlands, wet mineral soils, northern peatlands, termites, and ocean and geologic) is not strongly affected by the optimisation. However, the source distribution within these large categories changes under optimisation. For anthropogenic sources, e.g., $\mathrm{CH}_{4}$ emissions are shifted from oil and gas $(-4 \%)$ to increased emissions from ruminants $(+6 \%)$ and waste $(+1 \%$ to $+2 \%)$. Table 3 shows that the changes for the individual categories are substantial in absolute values. The optimisation also considerably reduces the associated error by $51 \%$ and $29 \%$ for oil and gas and ruminants, respectively. The transfer of emissions from oil and gas to domestic ruminants seems to be largely due to the difference in where these sources are on the planet: oil and gas emissions are heavily located in the Northern Hemisphere (e.g. Russia / Siberia), while domestic ruminant emissions are strong in South America. Focusing only on anthropogenic categories, the shift from oil and gas to ruminants largely reflects the increase in tropical / southern hemisphere emissions required by the inversion.

In regard to the natural sources, the optimisation affects mainly northern peatlands. Peatland $\mathrm{CH}_{4}$ emissions are reduced from $10 \%$ to $5 \%$ in $\mathrm{SC} 1$ and from $7 \%$ to $5 \%$ in $\mathrm{SC} 2$. The opposite is true for $\mathrm{CH}_{4}$ emissions from wet mineral soils and inundated wetlands (including rice agriculture). Although the relative contribution of emissions from these source types differ substantially between SC1 and SC2, the difference is preserved in the optimisation. This means that the inversion can not clearly differentiate between emissions from wet mineral soils or inundated wetlands. Emissions
Table 3. Regional total (anthropogenic+natural) emission changes following the optimisation of the LPJ (SC2) scenario using TM5$4 \mathrm{Dvar}$ for the year 2004 at a $1^{\circ} \times 1^{\circ}$ resolution. Given are prior and posterior total fluxes by region (top) and category (bottom) in $\mathrm{Tg} \mathrm{CH}_{4} \mathrm{yr}^{-1}$, their associated error and the estimated uncertainty reduction. The 13 land regions are given as defined in the TRANSCOM3 model intercomparison experiment (Gurney et al., 2002), while the 14th region, referred to as "Oceans", combines the 10 oceanic regions of TRANSCOM3.

\begin{tabular}{lccccc}
\hline Region & Prior. emis. & Post. emis. & Prior. error & Post. error & Uncert. red. \\
\hline Canada & 18.3 & 13.3 & 1.7 & 1.5 & $14 \%$ \\
USA & 32.4 & 51.3 & 4.0 & 2.2 & $46 \%$ \\
Central America & 26.2 & 36.2 & 2.4 & 2.1 & $13 \%$ \\
South America & 57.2 & 83.1 & 5.0 & 2.5 & $50 \%$ \\
NH Africa & 36.9 & 55.0 & 3.1 & 2.8 & $12 \%$ \\
SH Africa & 20.4 & 29.2 & 4.9 & 2.1 & $58 \%$ \\
Europe & 66.7 & 52.4 & 7.5 & 3.1 & $59 \%$ \\
Siberia & 35.0 & 27.7 & 4.9 & 2.2 & $56 \%$ \\
Arabia & 12.0 & 10.2 & 4.7 & 1.7 & $63 \%$ \\
South Asia & 59.3 & 45.8 & 8.0 & 3.2 & $60 \%$ \\
East Asia & 64.2 & 73.2 & 6.3 & 3.0 & $51 \%$ \\
Australia & 6.9 & 9.4 & 1.0 & 1.0 & $2 \%$ \\
Tropical Asia & 30.8 & 33.7 & 2.4 & 2.2 & $9 \%$ \\
Oceans & 28.4 & 27.8 & 1.4 & 1.3 & $5 \%$ \\
\hline Globe & 494.6 & 548.3 & 17.6 & 6.0 & $66 \%$ \\
\hline Category & Prior. emis. & Post. emis. & Prior. error & Post. error & Uncert. red. \\
\hline Coal mining & 31.7 & 36.6 & 6.6 & 4.5 & $32 \%$ \\
oil and gas & 68.8 & 52.8 & 9.4 & 4.6 & $51 \%$ \\
Ruminants & 97.1 & 135.4 & 9.1 & 6.4 & $29 \%$ \\
Biomass burning & 26.9 & 27.7 & 3.3 & 1.8 & $44 \%$ \\
Waste & 60.4 & 68.2 & 6.1 & 5.2 & $15 \%$ \\
Inundated wetlands & 75.2 & 80.4 & 3.5 & 3.0 & $12 \%$ \\
Wet mineral soils & 57.7 & 63.2 & 2.4 & 2.3 & $5 \%$ \\
Northern peatlands & 38.6 & 28.2 & 3.0 & 2.2 & $28 \%$ \\
Rice agriculture & 42.6 & 44.0 & 3.1 & 2.6 & $17 \%$ \\
Termites & 17.8 & 22.7 & 1.6 & 1.5 & $2 \%$ \\
Ocean \& geo & 16.7 & 14.9 & 1.0 & 1.0 & $2 \%$ \\
Soil uptake & -38.9 & -25.8 & 2.7 & 2.6 & $4 \%$ \\
\hline Globe & 494.6 & 548.3 & 17.6 & 6.0 & $66 \%$ \\
\hline & & & & &
\end{tabular}

from these two categories have a large spatial overlap, such that after transport in the atmosphere, surface concentrations and satellite measurements can not help to distinguish between them.

However, the inversion produces additional information on the spatial pattern for the LPJ simulated net exchange. Figure 6 shows the change in $\mathrm{CH}_{4}$ emissions and uptake, following optimisation, at grid cell resolution. Fluxes from northern peatlands are reduced in Scandinavia, Canada and Alaska (Fig. 6a), and tropical emissions (inundated wetlands, rice agriculture, wet mineral soils) are greatly reduced in Western South America, Bangladesh-India and Indonesia (Fig. 6bd). On the other hand, the optimisation suggests a net increase in Eastern South American and Central African emissions. The latter is partly achieved by a reduction in soil uptake (from 39 to $26 \mathrm{Tg} \mathrm{CH}_{4} \mathrm{yr}^{-1}$ globally, Fig. 6e). Emission changes for the optimisation of SC2 are given in Table 3 for each category and for each geographical region, as defined in the TRANSCOM3 model intercomparison experiment (Gurney et al., 2002). It can be seen from Table 3 and Fig. 6f that the net change in $\mathrm{CH}_{4}$ emissions is 


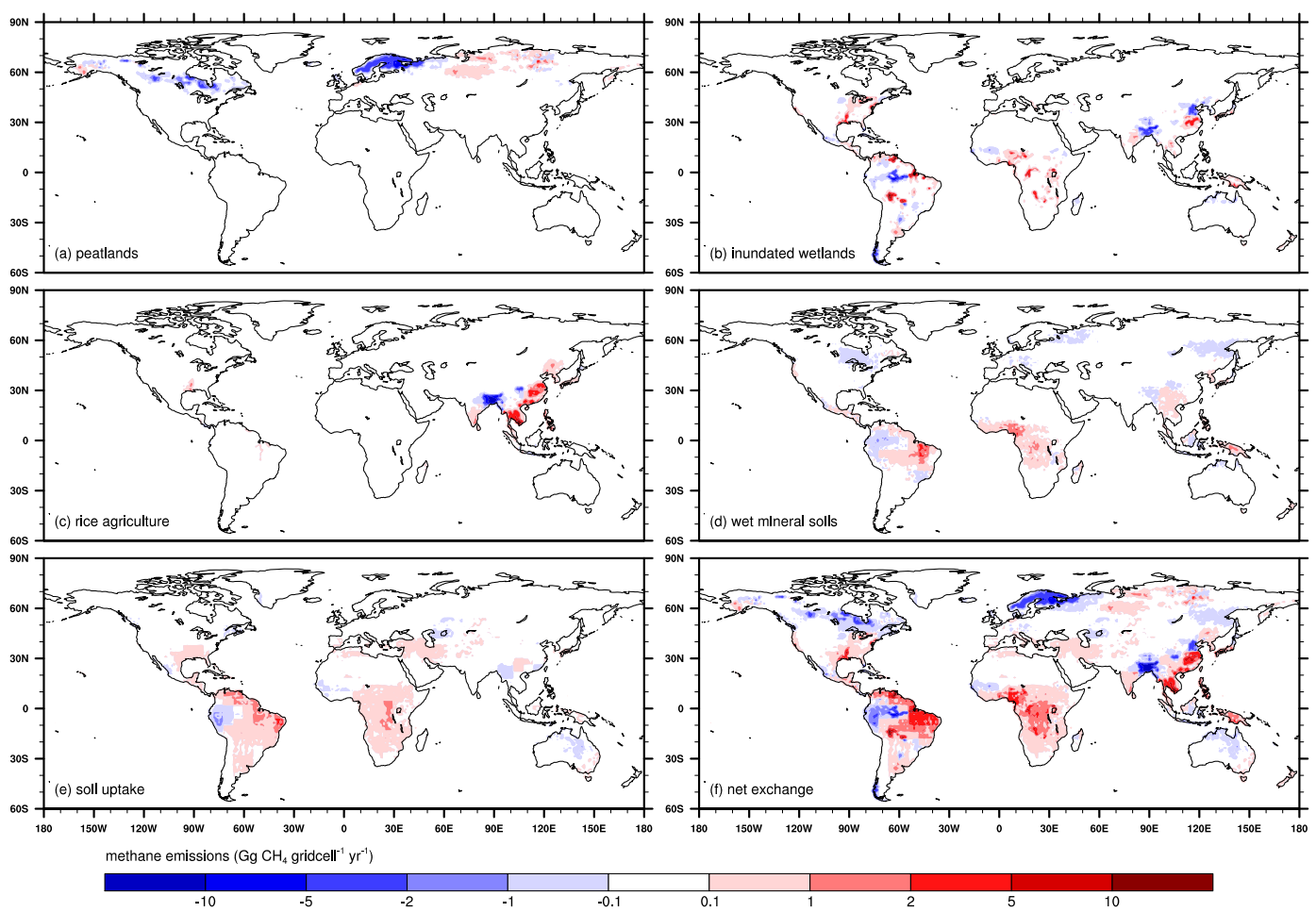

Fig. 6. Map of emission difference $\left(\mathrm{GgCH}_{4}\right.$ gridcell $\left.^{-1} \mathrm{yr}^{-1}\right)$ of fluxes before and after optimisation for the LPJ scenario SC2 in 2004 using TM5-4Dvar. Fluxes represent changes in the net exchange of the LPJ categories: (a) northern extra-tropical peatlands, (b) naturally inundated wetlands, (c) rice agriculture, (d) wet mineral soils, (e) soil uptake (positive numbers indicate a smaller uptake) and (f) sum of all fluxes (compare to Fig. 1).

relatively spread out over various regions, but with strong reductions/increases in particular regions. Regions with a large relative increase are the North American temperate and the North African region, while emissions from the Eurasian boreal region are strongly decreased. Note that the regional adjustments in Table 3 are for the total $\mathrm{CH}_{4}$ emissions per region and thus also include substantial changes in anthropogenic sources (Fig. 5). As mentioned above, most important are increased emissions from ruminants $(+40 \%)$, mostly confined to North-and South America and decreased emissions from oil and gas industry $(-23 \%)$ mostly confined to Eurasia. Regional changes in anthropogenic emissions as derived from TM5-4Dvar inversions using surface and SCIAMACHY $\mathrm{CH}_{4}$ observations have recently been presented by Bergamaschi et al. (2009). Table 3 also shows the globally integrated uncertainty reduction of the inversion per emission category. Although, the overall reduction in uncertainty is considerable (66\%), the atmospheric inversions can only give us estimates of how the LPJ fluxes should be corrected. The observations on its own are not a strong enough constraint to distinguish between all sources, because they have significant spatial overlap. As a result from the inversion both scenario seem to be consistent with the observational constraint.
In summary, the strongest constraint imposed by the observations on the LPJ-derived source and sink fluxes is the consistent reduction on northern peatland emissions in both scenarios, $\mathrm{SC} 1$ and $\mathrm{SC} 2$, to about $5 \%$ of total emissions (Fig. 5). Therefore, we evaluate the temporal evolution of northern peatlands over the years 2003-2005, using TM5-4Dvar and additionally using the LMDz-SACS inversion system. The evolution of monthly peatland emission anomalies over this time is shown for the prior, and the two posterior, emission estimates (resulting from the two inversions) in Fig. 7. The two inversions show quite large differences in the seasonality of posterior $\mathrm{CH}_{4}$ fluxes, both being consistent with the atmospheric concentrations. While the LMDz-SACS-optimised posterior emissions have a similar seasonal duration to the prior fluxes, the TM5-4Dvar-optimised posterior emission season is considerably shorter. The difference between the inversion systems is inherent to their set-up. Temporal correlations in TM5-4Dvar are category-dependent and are not being applied to seasonally varying emissions such as from the peatlands at high northern latitudes. In LMDz-SACS the total of all sources is constrained over eight-day periods, with no time correlation between these periods. The discrepancy in the results clearly show how uncertain seasonal fluxes by inversions are. On the other hand, both inversion results have a maximum correction in July and reductions in 


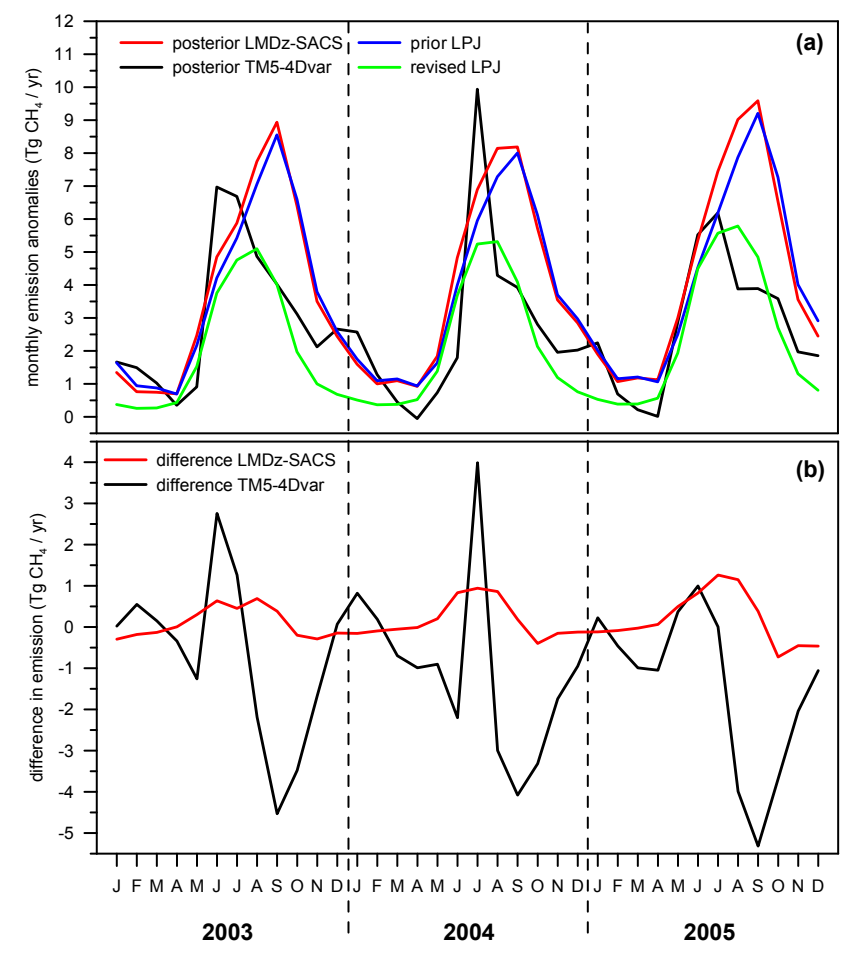

Fig. 7. Simulated $\mathrm{CH}_{4}$ emissions from northern extra-tropical (45$90^{\circ} \mathrm{N}$ ) peatlands for the years 2003-2005. Shown are priori emissions as calculated in LPJ and posterior emissions that have been optimised by atmospheric inversions with LMDz-SACS and TM54Dvar. Emissions are shown as absolute values (a) and as the difference of inverison results to the prior (b). The revised $\mathrm{LPJ} \mathrm{CH}_{4}$ emissions are obtained after including a more sophisticated parametrisation of the $\mathrm{CH}_{4}$ ebullition transport in the LPJ model (Wania et al., 2010b).

August-October (Fig. 7b). This suggests that northern peatland emissions apparently reach their maximum about one month earlier than simulated by LPJ.

The reasons for this disagreement between LPJ and the emissions inferred from observation by inversion lies in the separation of the three different pathways for $\mathrm{CH}_{4}$ to escape to the atmosphere. In $\mathrm{LPJ}, \mathrm{CH}_{4}$ fluxes from plant mediated transport and diffusion are highest in July, while ebullition fluxes from peatlands peak late in the season, causing the overall $\mathrm{CH}_{4}$ emissions to wrongly peak in September/October. In a revised version of LPJ we change the parametrisation of the ebullition, such that all excess $\mathrm{CH}_{4}$ is emitted immediately and at a lower threshold, leading to higher ebullition during summer. In the final version of the model (Wania et al., 2010b), simulated $\mathrm{CH}_{4}$ fluxes were recalibrated against site data using this new ebullition parametrisation. The recalibration results in slightly different

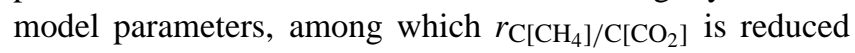
from $20 \%$ (SC2) to $10 \%$ (Wania et al., 2010b). As a consequence peatland $\mathrm{CH}_{4}$ emissions are strongly reduced (from 38.6 to $25.6 \mathrm{Tg} \mathrm{yr}^{-1}$ ) and the new ebullition parametrisation leads to a shift in seasonality. The revised LPJ seasonal emissions now have an improved time correlation with the TM54Dvar inversion results, where as before it was closer to the LMDz-SACS inversion results (Fig. 7). It is expected, that new inversions of the revised LPJ peatland emissions would lead to the same results.

\subsection{Interannual variability}

For the analysis of the interannual variabilty we set up an LPJ simulation using the new ebullition parametrisation and force it with the CRUNCEP reanalysis data set over the extended period 1990-2008. Due to the new model setup annual fluxes differ from values in SC1 and SC2. Therefore, we directly impose an agreement of the simulated $\mathrm{CH}_{4}$ exchange with the TM5-4Dvar inversion budget in 2004 (Table 3) by scaling LPJ parameters and thus linearly scaling emission patterns for each category: northern peatlands (from 25.6 to $28.2 \mathrm{Tg} \mathrm{yr}^{-1}$ in $2004 ; \times 1.10$ ), inundated wetlands and rice $\left(98.9\right.$ to $\left.124.4 \mathrm{Tg} \mathrm{yr}^{-1} ; \times 1.26\right)$, wet mineral soils $\left(48.7\right.$ to $\left.63.2 \mathrm{Tg} \mathrm{yr}^{-1} ; \times 1.30\right)$ and soil uptake $(-32.6$ to $\left.-25.8 \mathrm{Tg} \mathrm{yr}^{-1} ; \times 0.79\right)$. The scaling is explained for e.g. inundated wetlands and wet mineral soils by a change in

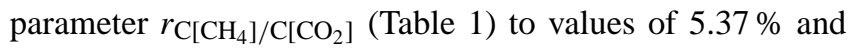
$0.67 \%$, respectively. Although, the individual source and sink attribution changes with the scaling, the impact on the interannual variability of simulated LPJ emissions is comparably small (see online replies to Spahni et al., 2011).

Using the LPJ emissions calibrated for 2004 we assess the interannual variability in the simulated $\mathrm{CH}_{4}$ exchange due to variations in the CRUNCEP climate input data. In Fig. 8 the LPJ-simulated $\mathrm{CH}_{4}$ fluxes in natural ecosystems (including rice agriculture) for the period 1990-2008 are compared to long term atmospheric synthesis inversions (updated from Bousquet et al., 2006), climate input variables and other LPJ output. Two apparent features are emerging. First, LPJ based natural ecosystem $\mathrm{CH}_{4}$ emissions (including rice agriculture) increase over the 1990s and beyond (Fig. 8a). This partially agrees with the trends derived from atmospheric synthesis inversions for global wetlands, with either constant or variable $\mathrm{OH}$ fields (updated from Bousquet et al., 2006). Second, the calculated anomaly (12 month running mean) of $\mathrm{CH}_{4}$ exchange of LPJ is smaller $\left( \pm 7.1 \mathrm{Tg} \mathrm{CH}_{4} \mathrm{yr}^{-1}\right)$ than the inversion estimate $\left( \pm 10.6 \mathrm{Tg} \mathrm{CH}_{4} \mathrm{yr}^{-1}\right.$ with constant and $\pm 11.5 \mathrm{Tg} \mathrm{CH}_{4} \mathrm{yr}^{-1}$ with variable $\mathrm{OH}$ ). The LPJ emission variability mainly reflects the variability of local fluxes due to climate variability and does not incorporate the variability of source area. Including this variability for naturally inundated wetlands for the years 1993-2000 (Prigent et al., 2007), the largest natural source of the LPJ categories, leads to a significantly different evolution of interannual emissions (Fig. 8a). Its variability is larger and the trend is negligible. This result confirms the finding of Ringeval et al. (2010) who show that the source area variability and flux variability for inundated 


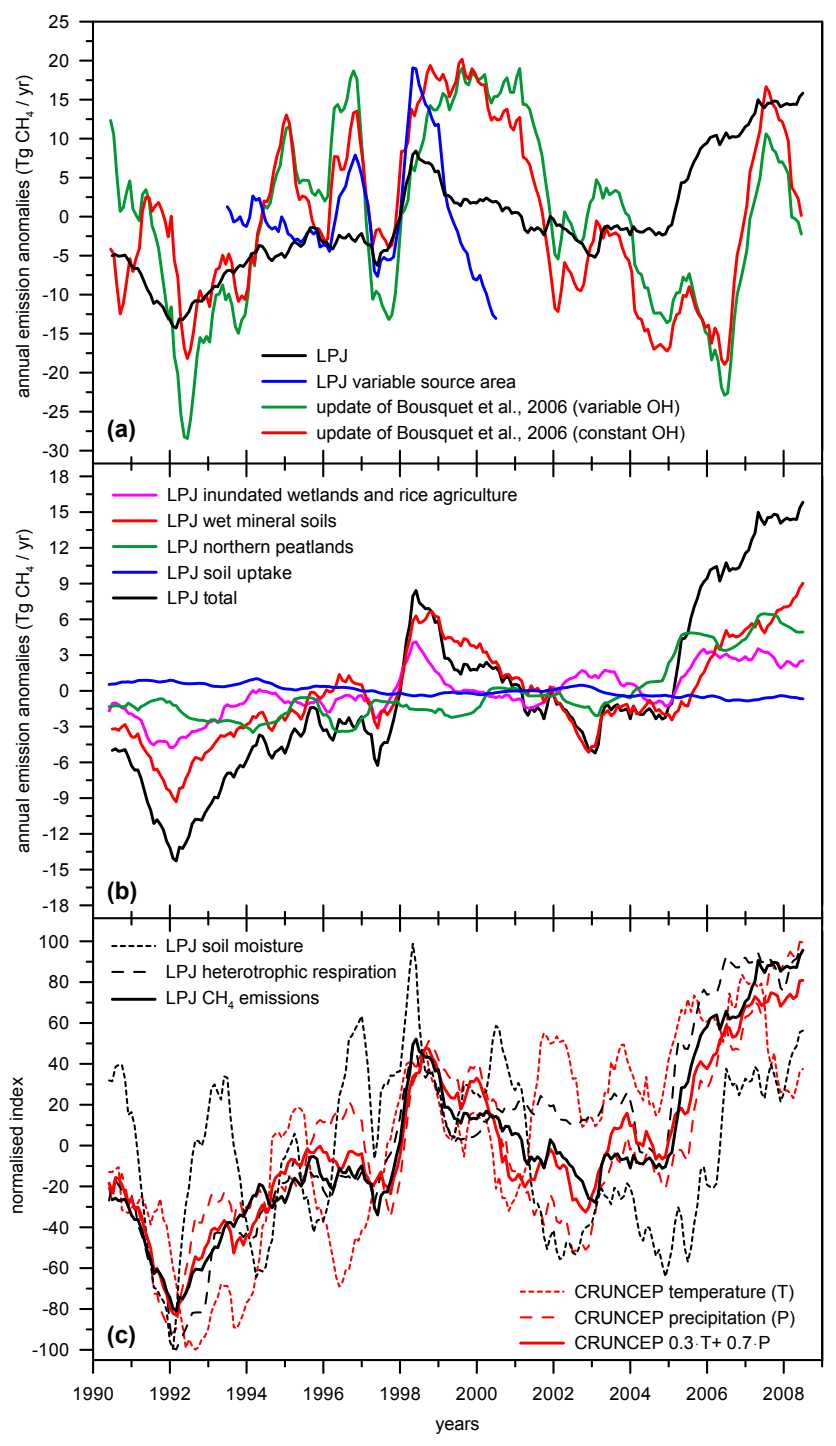

Fig. 8. Interannual variability in methane emissions. A centered 12month running mean filter has been applied to smooth monthly output. (a) Global $\mathrm{CH}_{4}$ emission anomalies simulated by LPJ (natural ecosystems and rice agriculture) for scenario SC2 are compared to synthetic inversion results for global wetlands updated from Bousquet et al. (2006). "LPJ variable source area" denotes emission anomalies for 1993-2000 calculated by using the observed monthly inundated area (Prigent et al., 2007). (b) Simulated methane emissions by categories. The negative trend in soil uptake fluxes means more uptake with time. (c) Trends and variability in normalised environmental variables. Shown are soil moisture and heterotrophic soil respiration simulated by LPJ, CRUNCEP temperature and precipitation averaged over land and a linear combination of the latter.

wetlands are not necessary linearly related, and both are important for $\mathrm{CH}_{4}$ emission variability.

In our approach the LPJ emission variability is composed of the different source and sink categories (Fig. 8b). Emissions from northern peatlands and naturally inundated wet- lands have a similar, but anti-correlated contribution to total source variability. Emissions from wet mineral soils show a larger variability and explain most of the total interannual variability. This can be partly explained by the soil moisture content. Its variability not only affects the $\mathrm{CH}_{4}$ fluxes, but also the source area of wet mineral soils. However, areas of northern peatlands and inundated wetlands are not directly related to soil moisture availability in our study. Soil uptake has a comparably small variability, but is steadily increasing and thus slightly compensating the trend in emissions. The main reason for the increase in total $\mathrm{CH}_{4}$ emissions is an increase in LPJ heterotrophic respiration. $\mathrm{HR}$ and $\mathrm{CH}_{4}$ emissions are highly correlated $\left(R^{2}=0.91\right) . \mathrm{CH}_{4}$ emissions go along with increasing temperature $\left(R^{2}=0.55\right)$ and precipitation $\left(R^{2}=0.83\right)$ over land as shown in Fig. 8c. Soil moisture content alone is not well correlated to $\mathrm{CH}_{4}$ emissions $\left(R^{2}=0.22\right)$. A good predictor for the simulated global $\mathrm{CH}_{4}$ emissions is a normalised index that combines global mean surface temperature (30\%) and global mean precipitation $(70 \%)$ over land, favouring high $\mathrm{CH}_{4}$ emissions under warm and wet conditions $\left(R^{2}=0.94\right)$.

\section{Discussion}

\subsection{LPJ scenarios and budgets}

Constraining natural $\mathrm{CH}_{4}$ emissions on a global scale has several main components. Observational data on the local scale (flux measurements) and large scale (global networks, satellite data and mapping) in our analysis provide the boundary conditions necessary to model $\mathrm{CH}_{4}$ fluxes at intermediate scales. LPJ further constrains emissions by simulating the biogeochemical processes. The inversion systems then constrain emissions by calculation of atmospheric transport and $\mathrm{CH}_{4}$ loss from the observed atmospheric $\mathrm{CH}_{4}$ concentration distribution. Despite these various observational and modelling constraints, there remains more than one solution for the global source and sink distribution. Finding "the optimal solution" certainly takes a lot of effort at all scales. In this study we present two LPJ emission scenarios, SC1 and SC2 (Table 1, Table 2, Fig. 5) that are evaluated. Northern peatland emissions for both scenarios are within the range of earlier estimates of 31 to $106 \mathrm{Tg} \mathrm{CH}_{4} \mathrm{yr}^{-1}$ (Zhuang et al., 2004). Yet, our atmospheric inversion results suggest northern peatland emissions being even lower than $\mathrm{SC} 2\left(39 \mathrm{Tg} \mathrm{CH}_{4} \mathrm{yr}^{-1}\right)$ in 2004, at about $28 \mathrm{Tg} \mathrm{CH}_{4} \mathrm{yr}^{-1}$. This is in line with an earlier inversion study (Chen and Prinn, 2006), in which a prior estimate of $43 \pm 65 \mathrm{Tg} \mathrm{yr}^{-1}$ for Northern Hemisphere emissions was reduced to $33 \pm 18 \mathrm{Tg} \mathrm{CH}_{4} \mathrm{yr}^{-1}$. This study also estimated $223 \mathrm{Tg} \mathrm{yr}^{-1}$ for remaining wet ecosystem methane sources (including rice agriculture), which is more or less in line with our estimate of $204 \mathrm{Tg} \mathrm{yr}^{-1}$.

A decreased northern source asks for a compensation in other sources. Tropical sources have already been increased 
from $\mathrm{SC} 1$ to $\mathrm{SC} 2$ by a $70 \%$ larger carbon conversion rate $r_{\left.\mathrm{C}\left[\mathrm{CH}_{4}\right] / \mathrm{C}_{[} \mathrm{CO}_{2}\right]}$ (tuning parameter) for natural inundated wetlands and rice agriculture. Since the two categories use the same parametrisation, an additional increase in

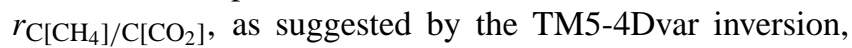
leads to slightly larger $\mathrm{CH}_{4}$ emission from rice agriculture (Fig. 2). This limits $\mathrm{CH}_{4}$ emissions from inundated wetlands from $45^{\circ} \mathrm{N}$ to $60^{\circ} \mathrm{S}$ to $\sim 80 \mathrm{Tg} \mathrm{yr}^{-1}$. Additionally, wet mineral soils contribute $\sim 50 \mathrm{Tg} \mathrm{CH}_{4} \mathrm{yr}^{-1}$ summing to a total of $\sim 130 \mathrm{Tg} \mathrm{CH}_{4} \mathrm{yr}^{-1}$ in this latitudinal band. A separation of these two source categories by the inversion results has proven to be difficult. Overall, the reduced northern peatland source in $\mathrm{SC} 2$ compared to $\mathrm{SC} 1$ and the good agreement with emissions from rice agriculture, suggests that $\mathrm{SC} 2$ is a more plausible scenario than SC1.

Total natural ecosystem sources $\left(171.5 \mathrm{Tg} \mathrm{CH}_{4} \mathrm{yr}^{-1}\right)$ and the soil sink (38.9 $\mathrm{Tg} \mathrm{CH}_{4} \mathrm{yr}^{-1}$ ) of SC2 in 2004 result in a prior estimated net soil source of $132.6 \mathrm{Tg} \mathrm{CH}_{4} \mathrm{yr}^{-1}$ (no rice agriculture). Using optimised fluxes from the TM54Dvar inversion based on SC2 (Table 3), net emissions yield $145 \mathrm{Tg} \mathrm{CH}_{4} \mathrm{yr}^{-1}$ in 2004. Both estimates are in agreement with the $145 \pm 25 \mathrm{Tg} \mathrm{CH}_{4} \mathrm{yr}^{-1}$ estimated by Chen and Prinn (2006) for the years $1996-2001$ and $137 \pm 15 \mathrm{Tg} \mathrm{CH}_{4} \mathrm{yr}^{-1}$ estimated by Bousquet et al. (2006) for the years 19842003. The "bottom-up" estimate for LPJ emissions scaled to 2004 inversion results (Fig. 8b) yields an average of $147 \mathrm{TgCH}_{4} \mathrm{yr}^{-1}$ and a variability of $\pm 7 \mathrm{Tg} \mathrm{CH}_{4} \mathrm{yr}^{-1}$ over the years 1990-2008.

\subsection{LPJ trends}

All natural LPJ flux categories show an increase over the years 1990-2008 (Fig. 8b) that becomes $+1.03 \mathrm{Tg} \mathrm{CH}_{4} \mathrm{yr}^{-1}$ without rice emissions and $+1.11 \mathrm{Tg} \mathrm{CH}_{4} \mathrm{yr}^{-1}$ when rice emissions are included. The increase in simulated $\mathrm{CH}_{4}$ emissions is attributed to enhanced soil respiration resulting from the observed rise in land temperature and in atmospheric carbon dioxide that were used as input. With a conversion factor of $2.78 \mathrm{Tg} \mathrm{CH}_{4} \mathrm{ppbv}^{-1}$ and no change in atmospheric loss this implies an atmospheric $\mathrm{CH}_{4}$ increase of 0.37 and $0.4 \mathrm{ppbv} \mathrm{yr}^{-1}$, respectively, which is very small and about the observed atmospheric growth rate for 2000-2006 (Dlugokencky et al., 2009). This trend does not support the hypothesis that natural wet ecosystem sources are fully responsible for the decline in the atmospheric growth rate since 1990. However, the increase in global emission fluxes could have been modulated or compensated by a decrease in global wetland area (Prigent et al., 2007; Ringeval et al., 2010). An alternative explanation of the limited growth in atmospheric $\mathrm{CH}_{4}$ despite rising anthropogenic and natural emissions could be an increase in the tropospheric $\mathrm{OH}$ loss over this time period in relation to changing atmospheric chemistry following increases in air pollution (Dalsøren et al., 2009; van Weele and van Velthoven, 2010).
The last decade shows a clear temporal division in the $\mathrm{CH}_{4}$ emission trends simulated by LPJ. The period 1999-2004 shows a small decrease $\left(-1.03 \mathrm{Tg} \mathrm{CH}_{4} \mathrm{yr}^{-1}\right)$ in agreement with atmospheric synthesis inversions (Fig. 8a) and conclusions by Bousquet et al. (2006), while the period 20052008 shows a considerable increase $\left(+3.62 \mathrm{Tg} \mathrm{CH}_{4} \mathrm{yr}^{-1}\right.$, Fig. 8a,b). This increase contributes to the observed maximum in atmospheric growth rate in 2007 (Dlugokencky et al., 2009). The biggest contribution of the 2008-2004 difference in simulated $\mathrm{CH}_{4}$ emissions $\left(17.33 \mathrm{Tg} \mathrm{CH}_{4}\right)$ comes from wet mineral soils $(56.6 \%)$. Northern peatland emissions $(24.3 \%)$ and emissions from inundated wetlands including rice agriculture $(20.5 \%)$ contributed similarly, but less, to the rise in $\mathrm{CH}_{4}$. The LPJ run also suggests that only post 2005 are the inter-annual emission anomalies of peatlands and inundated wetlands not anti-correlated (Fig. 8b). The compensation of emissions through an increased soil sink is small $(-1.4 \%)$.

This source attribution agrees with the finding of Dlugokencky et al. (2009), namely that despite the emission increase at Arctic latitudes, the largest increase in atmospheric $\mathrm{CH}_{4}$ concentrations in 2007 happened in the tropics. This is represented in the simulation by the dominant contribution in 2006/2007 from the low-latitude sources wet mineral soils, inundated wetlands and rice agriculture (Fig. 8b). Emission fluxes could be modulated by variations in global wetland area, which is partly considered by the change in emission area of wet mineral soils that seem to play an important role for the inter-annual $\mathrm{CH}_{4}$ variability. The inclusion of a hydrological module in a DGVM, that calculates wetland area in addition to wetland fluxes, as well as more observational constraints are needed to properly address questions on long term trends in global $\mathrm{CH}_{4}$ emissions.

\section{Summary and conclusions}

In a multiple model approach we derive estimates for global $\mathrm{CH}_{4}$ emissions and uptake in organic and mineral soils that are in agreement with atmospheric observations. We show that the global $\mathrm{CH}_{4}$ source category usually summarised in the literature as "wetlands" can be usefully broken down into process-defined subcategories: northern peatlands, naturally inundated wetlands, rice agriculture and mineral soils. Mineral soils are mostly treated in the literature as a potential $\mathrm{CH}_{4}$ sink, but unsaturated mineral soils are also a potential $\mathrm{CH}_{4}$ source. Even if most of the produced $\mathrm{CH}_{4}$ is oxidised and fluxes per $\mathrm{m}^{2}$ are relatively small, areas with moderately high soil moisture are very extensive and result according to our calculations, in gobal emissions of $\sim 60 \mathrm{Tg} \mathrm{CH}_{4} \mathrm{yr}^{-1}$. Natural $\mathrm{CH}_{4}$ fluxes simulated by LPJ are scaled to global totals using fractional source area maps (Prigent et al., 2007; Global Soil Data Task Group, 2000; Leff et al., 2004). With this global approach we find $\mathrm{CH}_{4}$ emissions from rice agriculture in SE Asia in agreement with recent EDGAR inventory estimates (EC-JRC/PBL, 2009). The resulting global $\mathrm{CH}_{4}$ emission distribution by latitude for the LPJ categories 
generally compares well to reconstructions based on concentration and gravity field satellite observations (Bloom et al., 2010). However, in high-latitudes $\left(60^{\circ}-70^{\circ} \mathrm{N}\right)$, which are not well constrained by satellite observations, the LPJ peatland emissions are relatively high compared to the estimate by Bloom et al. (2010).

From the results of two different sets of parametrisations of our biogeochemical model (SC1, SC2) supplemented with other natural and anthropogenic sources, we derive two global $\mathrm{CH}_{4}$ budgets that are tested against atmospheric observations, both ground based and space borne, using the TM5-4Dvar and LMDz-SACS inversion systems. The inversions show that $\mathrm{CH}_{4}$ emissions predicted by LPJ for northern peatlands are overestimated in total, and reach their annual maximum about one month late. Although the two derived scenarios SC1 and SC2 differ substantially in the emissions attributed to wet mineral soils and inundated wetlands, the inversion results can not readily distingusih between these two emission categories. This study thus clearly points out the need for further observational constraints and inversion system for individual source categories.

The inversion results for the year 2004 suggest changes to the $\mathrm{CH}_{4}$ model parameters in LPJ and the offline calculations. The atmospheric inversions thus can help to point out deficiencies in the biogeochemical model in a diagnostic way. A simulation over the period of 1990-2008, using LPJ with these revised and calibrated parameters suggests that global net emissions of LPJ categories slightly increased $\left(+1.11 \mathrm{Tg} \mathrm{CH}_{4} \mathrm{yr}^{-1}\right)$. Therefore, alternative explanations for the observed decline in atmospheric $\mathrm{CH}_{4}$ growth over this time period are needed, for example a reduction in global inundated wetland area (Ringeval et al., 2010) and/or changes in atmospheric chemistry from increasing air pollution (e.g. $\mathrm{NO}_{\mathrm{x}}$ concentration) reducing the global $\mathrm{CH}_{4}$ chemical lifetime against $\mathrm{OH}$ (Dalsøren et al., 2009; van Weele and van Velthoven, 2010). Our results for 2006-2008 suggest that enhanced natural $\mathrm{CH}_{4}$ emissions from wet ecosystems, and particularly mineral soils, mainly from the tropics, can partly explain the renewed growth of atmospheric $\mathrm{CH}_{4}$ in 2007 (Dlugokencky et al., 2009).

The geographical distribution of corrections to LPJ fluxes by source and sink categories can greatly improve the understanding and representation of $\mathrm{CH}_{4}$ relevant processes in biogeochemical models. Our study also shows that in addition to accurate global wetland extent (Ringeval et al., 2010), a good characterisation of the different wetland types is needed in "bottom-up" biogeochemical process models. It will continue to be very difficult to identify different source and sink changes from atmospheric inversion calculations alone. An iteration of both modelling approaches together with observational constraints, as presented in this study, offers the potential to further constraining global $\mathrm{CH}_{4}$ emissions from individual sources and their variability on various temporal and spatial scales.

\section{Appendix A}

\section{Evaluation of modelled LPJ emissions}

\section{A1 Carbon conversion ratio calculation}

Basically the carbon conversion ratio $\left(r_{\left.\left.\mathrm{C}_{[} \mathrm{CH}_{4}\right] / \mathrm{C}_{[} \mathrm{CO}_{2}\right]}\right)$ for wet mineral soils and for inundated wetlands are global tuning parameters. They must satisfy two criteria: (i) the global $\mathrm{CH}_{4}$ budget and (ii) regional flux estimates.

(i) Total $\mathrm{CH}_{4}$ emissions from wet mineral soils and inundated wetlands have to fit within the global budget. Here we initially used the budget of Bousquet et al. (2006). Based on simulated emissions from inundated wetlands, rice paddies, peatlands and soil uptake, we can derive the magnitude of methane emissions of global wet mineral soils or vice versa for inundated wetlands. The carbon conversion ratio is then tuned in order that the categories emissions match this global source.

(ii) This parameter must additionally be chosen in order to let LPJ fluxes from wet mineral soils match the range of observed fluxes (Table A). In a similar way for inundated wetlands the carbon conversion ratio must lie within a reasonable range for wetland emissions (e.g. compare to values reported in Table 1 of Christensen et al., 1996).

In this study we have chosen to vary this parameter as it is considered to be the most uncertain in our approach of methane emission modelling. Many of the other model parameters are physically or biogeochemically better constrained.

\section{A2 Wet mineral soils}

For the two scenarios $\mathrm{SC} 1$ and $\mathrm{SC} 2$ the carbon conversion ratio for wet mineral soils was fixed at $0.52 \%$ to match roughly the annual emission range (Table A). Together with the soil moisture thresholds $(85 \%$ whe for SC1 and $95 \%$ whe for $\mathrm{SC} 2$ ) one can calculate global emissions from wet mineral soils (Fig. 1 and Fig. A1). Knowing the global budget (Bousquet et al., 2006) and other LPJ derived sources and sinks one can estimate the global emissions from inundated wetlands. From the global total one can finally deduce the carbon conversion ratio of inundated wetlands to $2.4 \%$ (SC1) and $4.15 \%$ (SC2). Nevertheless, the carbon conversion ratios remain global tuning numbers that can be changed, as long as criteria (i) and (ii) are fulfilled. For the revised LPJ fluxes as described in Sect. 4.3 the carbon conversion ratios have been retuned to $5.37 \%$ for inundated wetlands and $0.67 \%$ for wet mineral soils. 


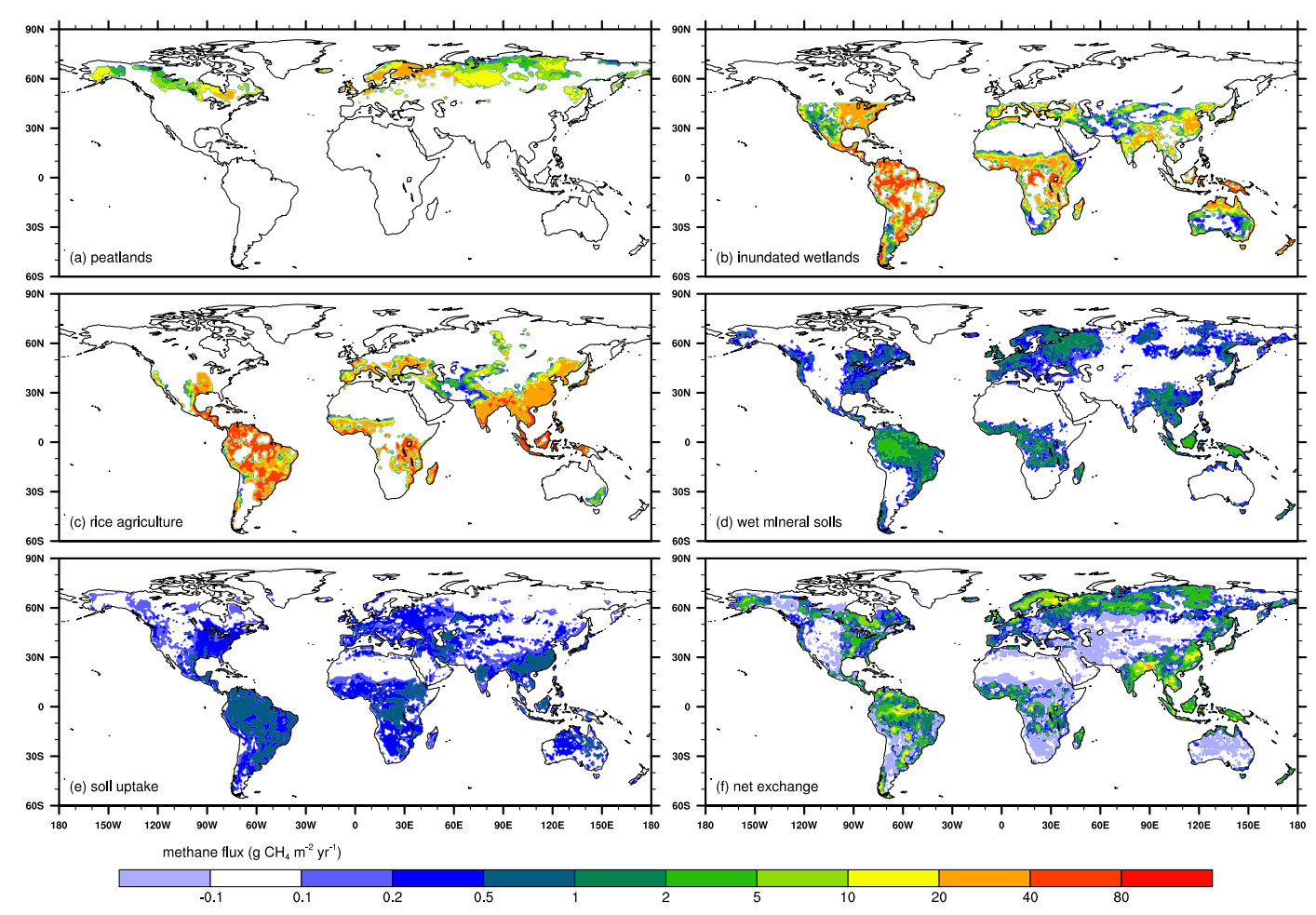

Fig. A1. Alternative presentation of Fig. 1 with $\mathrm{CH}_{4}$ fluxes per area instead of per grid cell for the individual categories (a-e) and the category weighted net flux (f). Note that here emissions from individual categories (a-e) are not weighted by their fractional cover ( $f_{\text {peat }}, f_{\text {natwet }}, f_{\text {rice }}, f_{\text {wetsoil }}$, see Sect. 3) and thus are non-area-weighted. Further, none of the subplots (a-f) take account of the decreasing grid cell area with higher latitude.

\section{A3 Comparison with field measurements}

Comparing simulated global $\mathrm{CH}_{4}$ fluxes with field measurements from individual sites, needs an upscaling one way or the other. This bears the risk for introducing large uncertainties. This is especially true for a trace gas like atmospheric $\mathrm{CH}_{4}$ that has large emission variability in space and time. We thus compiled a list of studies (Table A) that give a rough estimate on how large the potential $\mathrm{CH}_{4}$ source from wet mineral soils can be. Sites are well distributed over the world and cover different ecosystems. Fluxes were measured directly over non-saturated soils or over the canopy of trees. As indicated in Table A measured fluxes are given for different periods of the year and thus do not always represent the annual mean. LPJ fluxes of wet mineral soils are averaged (i) temporally and (ii) spatially.

(i) Annual average LPJ fluxes are comparable to observed annual fluxes. LPJ emission rates in months with maximum emissions are considerably larger and give an upper range for simulated emissions.

(ii) By comparing site flux data we implicitely assume that measurements are representative for a larger area, in our case for a $1^{\circ} \times 1^{\circ}$ latitude/longitude grid cell size. For some sites LPJ does simulate zero emissions from wet mineral soils because of very low soil moisture content (Sect. A2). In this case we also calculate the spatial average or the spatial maximum flux for a larger region of the size of $\sim 10^{\circ} \times 10^{\circ}$ latitude/longitude, indicated in Table A with ra and rm, respectively.

Monthly emission rates of up to $140 \mathrm{mgCH}_{4} \mathrm{~m}^{-2} \mathrm{~d}^{-1}$ are measured over 2 months in a tropical forest (Teh et al., 2005), albeit a very large proportion is oxidized in the soil. If there would be zero emissions for the other 10 months, the annual average flux would still be equivalent to $23.3 \mathrm{mg} \mathrm{CH}_{4} \mathrm{~m}^{-2} \mathrm{~d}^{-1}$. This is more than the range of annual average emissions simulated from LPJ wet mineral soils (Table A).

\section{Appendix B}

\section{Atmospheric inversion using 4D-Var}

\section{B1 Comparison of the inversions}

The two inversion systems used in this study were developed independently at two different research centers and thus represent two distinct implementations of a similar technique. The two systems differ in three main ways: the transport model used (and its adjoint), the estimation of background 
Table A. Comparison of site data and LPJ (SC2) $\mathrm{CH}_{4}$ fluxes for individual years from studies that classify as a "wet mineral soil" source. Fluxes are given in $\mathrm{mg} \mathrm{CH}_{4} \mathrm{~m}^{-2} \mathrm{~d}^{-1}$. Note that fluxes have been measured for individual ecosystems (sec. forest = secondary forest) and represent the average or the maximum $(\mathrm{m})$ flux observed for a certain period (annual/seasonal). LPJ fluxes are given for the annual average and for the month with maximum emissions in the respective year, as well as for different spatial extents: either for the flux of the grid cell at the site (s), for the average flux of grid cells representing a larger region (ra) or for the maximum flux of grid cells representing a larger region (rm). Uncertainty in measured mean flux or flux variability is very large i.e. $\pm 20 \%$ or more.

\begin{tabular}{|c|c|c|c|c|c|c|}
\hline Measurements & & & & Data & LPJ & \\
\hline Reference & year & ecosystem & period & $\begin{array}{l}\text { annual/ } \\
\text { seasonal }\end{array}$ & $\begin{array}{l}\text { annual } \\
\text { average }\end{array}$ & $\begin{array}{l}\text { monthly } \\
\max \text {. }\end{array}$ \\
\hline Sanhueza and Donoso 2006 & 1990 & grass savanna & 2 weeks & 0.52 & $0.74^{s}$ & $4.47^{\mathrm{s}}$ \\
\hline Kammann et al. 2001 & 1996 & grassland & 2 months & $0.16^{\mathrm{m}}$ & $1.40^{\mathrm{s}}$ & $8.18^{\mathrm{s}}$ \\
\hline \multirow[t]{4}{*}{ Otter and Scholes 2000} & 1996 & dry flood plain & 3 months & $4.80^{\mathrm{m}}$ & $3.26^{\mathrm{rm}}$ & $20.82^{\mathrm{rm}}$ \\
\hline & & savanna & 3 months & $1.68^{\mathrm{m}}$ & $0.05^{\mathrm{s}}$ & $0.64^{\mathrm{s}}$ \\
\hline & 1997 & dry flood plain & 3 months & $4.80^{\mathrm{m}}$ & $4.17^{\mathrm{rm}}$ & $21.41^{\mathrm{rm}}$ \\
\hline & & savanna & 3 months & $1.68^{\mathrm{m}}$ & $0.00^{\mathrm{s}}$ & $0.00^{\mathrm{s}}$ \\
\hline \multirow[t]{2}{*}{ Ishizuka 2002} & 1998 & tropical forest & 18 months & 0.13 & $0.00^{\mathrm{s}}$ & $0.00^{\mathrm{s}}$ \\
\hline & & & & & $5.45^{\mathrm{ra}}$ & $11.20^{\mathrm{ra}}$ \\
\hline \multirow[t]{6}{*}{ Hadi et al. 2005} & 1999 & sec. forest & 1 month & 0.00 & $0.00^{\mathrm{s}}$ & $0.00^{\mathrm{s}}$ \\
\hline & & sec. forest & 1 month & 0.32 & $6.94^{\mathrm{ra}}$ & $12.35^{\mathrm{ra}}$ \\
\hline & & sec. forest & 1 month & 0.96 & & \\
\hline & & sec. forest & 1 month & 46.72 & & \\
\hline & 2000 & sec. forest & 1 month & 1.28 & $0.00^{\mathrm{s}}$ & $0.00^{\mathrm{s}}$ \\
\hline & & sec. forest & 1 month & 4.16 & $6.94^{\mathrm{ra}}$ & $12.35^{\mathrm{ra}}$ \\
\hline Inubushi et al. 2003 & 2000 & sec. forest & 1 year & 3.29 & $6.94^{\mathrm{ra}}$ & $12.35^{\mathrm{ra}}$ \\
\hline \multirow[t]{2}{*}{ Simona et al. 2004} & 2000 & tree savanna & 1 year & 0.19 & $0.77^{\mathrm{ra}}$ & $6.11^{\mathrm{ra}}$ \\
\hline & & grass savanna & 1 year & 0.23 & & \\
\hline \multirow[t]{4}{*}{ Teh et al. 2005} & 2001 & tropical forest & 2 months & 30.41 & $0.00^{\mathrm{s}}$ & $0.00^{\mathrm{s}}$ \\
\hline & & & & & $11.76^{\mathrm{rm}}$ & $22.88^{\mathrm{rm}}$ \\
\hline & 2002 & tropical forest & 2 months & 139.62 & $0.00^{\mathrm{s}}$ & $0.00^{\mathrm{s}}$ \\
\hline & & & & & $11.73^{\mathrm{rm}}$ & $22.82^{\mathrm{rm}}$ \\
\hline Melling et al. 2005 & 2002 & tropical forest & 1 year & 0.07 & $0.00^{\mathrm{s}}$ & $0.00^{\mathrm{s}}$ \\
\hline \multirow[t]{3}{*}{ Yan et al. 2008} & 2003 & tropical forest & 1 year & $4.18^{\mathrm{m}}$ & $2.53^{\mathrm{s}}$ & $8.00^{\mathrm{s}}$ \\
\hline & & tropical forest & 1 year & $1.65^{\mathrm{m}}$ & & \\
\hline & & tropical forest & 1 year & $5.34^{\mathrm{m}}$ & & \\
\hline \multirow[t]{6}{*}{ Carmo et al. 2006} & 2004 & tropical forest & 1 week & 5.10 & $5.93^{\mathrm{s}}$ & $12.60^{\mathrm{s}}$ \\
\hline & 2004 & tropical forest & 1 week & 6.90 & $4.89^{\mathrm{S}}$ & $8.74^{\mathrm{s}}$ \\
\hline & 2004 & tropical forest & 1 week & 3.70 & $4.09^{\mathrm{s}}$ & $8.42^{\mathrm{s}}$ \\
\hline & 2004 & tropical forest & 1 week & 2.00 & $5.93^{\mathrm{s}}$ & $12.60^{\mathrm{s}}$ \\
\hline & 2004 & tropical forest & 1 week & 3.60 & $4.09^{\mathrm{s}}$ & $8.42^{\mathrm{s}}$ \\
\hline & 2005 & tropical forest & 1 week & 20.60 & $3.46^{\mathrm{s}}$ & $8.40^{\mathrm{s}}$ \\
\hline \multirow[t]{3}{*}{ Peichl et al. 2010} & 2006 & pine forest & 7 months & 0.70 & $1.05^{\mathrm{s}}$ & $4.89^{\mathrm{s}}$ \\
\hline & & pine forest & 7 months & 0.43 & & \\
\hline & & pine forest & 7 months & 0.38 & & \\
\hline Werner et al. 2007 & 2007 & tropical forest & 2 months & $3.19^{\mathrm{m}}$ & $1.51^{\mathrm{s}}$ & $18.12^{\mathrm{s}}$ \\
\hline Annual emission range & & & & $\sim 0.1-23.3$ & $\sim 0.1-11.8$ & $\sim 0.6-22.9$ \\
\hline
\end{tabular}

error covariances, and the composition of the control (or optimisation) vector. The TM5-4DVar system is described more closely in Meirink et al. (2008a,b) and the sources cited therein, and the LMDz-SACS system is described in (Pison et al., 2009).

\section{B1.1 Transport models}

The TM5-4DVar system connects emissions to concentrations using the methane-tracer version of the chemical transport model TM5 (Krol et al., 2005; Bergamaschi et al., 2007). In the simulations presented here, TM5 is run on a $6^{\circ} \times 4^{\circ}$ (longitude-latitude) grid and 25 sigma-pressure 
vertical levels. Transport in TM5 is driven by meteorological fields from 6-hourly forecasts of the ECMWF operational model. The reaction between $\mathrm{CH}_{4}$ and $\mathrm{OH}$ is modelled by a described, constant $k[\mathrm{OH}]$ field (Bergamaschi et al., 2007).

In the LMDz-SACS system, the model used to link emissions to concentrations is the off-line version of the atmospheric transport model LMDz (Laboratoire de Météorologie Dynamique Zoom, Hourdin et al., 2006) coupled with the atmospheric chemistry module SACS (Simplified Atmospheric Chemistry System, Pison et al., 2009), a simplified version of the full chemistry model INCA (Hauglustaine et al., 2004; Folberth et al., 2005), limited to the main components of the methane oxidation chain $\left(\mathrm{CH}_{4}\right.$, formaldehyde ( $\mathrm{HCHO}), \mathrm{CO}$ and $\mathrm{H}_{2}$ ). $\mathrm{OH}$ radicals are optimised within the same inversion framework using methyl-chloroform (MCF) surface observations. LMDzs grid is $3.75^{\circ} \times 2.5^{\circ}$ (longitudelatitude) on 19 sigma-pressure levels. The air mass fluxes are pre-computed by the on-line $\mathrm{LMDz}$ version nudged to winds from weather analysis.

\section{B1.2 Estimation of background error}

In the TM5-4DVar system, errors are estimated by assuming $100 \%$-uncertainty in the flux per emission category per gridcell. In addition, the correlation between gridcells is assumed as a Gaussian function with a decorrelation length of $500 \mathrm{~km}$. Practically, this means (1) that gridcells with greater prior emissions are considered to be more uncertain, and vice versa, and (2) that the inversion's adjustment in each gridcell is dependent on the adjustment in nearby gridcells. For source types that are seasonally varying (wet ecosystems, and biomass burning), no correlation is assumed between monthly fluxes. For the other sources, the temporal correlation is modelled as an exponential decay with a decorrelation time of 9.5 months.

In the LMDz-SACS inversion system, errors for $\mathrm{CH}_{4}$ fluxes are estimated by assuming an uncertainty in the (total) emission flux of $100 \%$ of the maximum flux over the cell and its eight neighbors during each month. This allow local variations in the spatial pattern of the inventory to occur. The correlations between gridcells are modelled as described in Chevallier et al. (2005) with correlation lengths of $500 \mathrm{~km}$ on land and no time correlations.

\section{B1.3 Control vector and cost function minimization}

In both systems, the adjoint of the respective transport models is used to minimise a cost function, that is a function of the misfit between predicted and observed $\mathrm{CH}_{4}$ concentrations (Chevallier et al., 2005). The set of model parameters with respect to which the cost function is minimised is called the control vector. In the TM5-4DVar system, the control vector is comprised of monthly methane fluxes per gridcell per source, plus the initial 3-D $\mathrm{CH}_{4}$ concentration field. The minimization of the cost function is performed using the Lanczos algorithm.

In the LMDz-SACS system, the control vector contains 8-day average net surface fluxes per grid cell of $\mathrm{CO}, \mathrm{CH}_{4}$, $\mathrm{MCF}$, and $\mathrm{H}_{2}$, the 8-day average production of $\mathrm{HCHO}$ per model column, 8-day average $\mathrm{OH}$ column-average concentration over four latitude bands (Bousquet et al., 2005), and the initial-time concentration fields of $\mathrm{CO}, \mathrm{CH}_{4}, \mathrm{MCF}$, and $\mathrm{H}_{2}$. In this system the cost function and the norm of its gradient (computed by the adjoint) are minimised with the algorithm M1QN3 (Gilbert and Lemaréchal, 1989).

Since the LMDz-SACS system does not provide an optimisation by category per se, we select grid cells with more than $90 \%$ peatland emissions in the prior. Then we assume that optimised peatland emissions fully account for changes in the posterior. This works quite well because peatlands are localised in the boreal region with little interference from other source types. Emissions from selected grid cells are then rescaled to reflect total peatland emissions. The downside is that the information of total peatland emissions is lost, but we gain information on the temporal optimisation for a single category. Resulting emission anomalies are shown in Fig. 7.

\section{B2 Surface observations}

Surface observations of $\mathrm{CH}_{4}$ concentration are made by NOAA, CSIRO, AGAGE, NIWA, JMA/MRI, EC, SAWS plus the RAMCES (Réseau Atmosphérique de Mesure des Composés à Effet de Serre) network coordinated by LSCE. These data are available through the World Data Centre for Greenhouse Gases (2008) (WDCGG) website. Instantaneous values and 24-h averages were used at stations with at least one value per month during the period of interest. Continuous measurements by the AGAGE network have been averaged over $24 \mathrm{~h}$ for convenience. All $\mathrm{CH}_{4}$ measurements were adjusted on the NOAA 2004 calibration scale (Dlugokencky et al., 2005) with the factors provided by GLOBALVIEW$\mathrm{CH}_{4}$ (2009).

In the TM5-4DVar system, station observations are averaged into 3-hourly bins and compared to mean concentrations per 3-h time step, resulting in a total of 7912 station observations of $\mathrm{CH}_{4}$ concentration assimilated from 2003 to 2005. The uncertainty assumed per station observation is estimated by a $3 \mathrm{ppb}$ measurement error, plus a representativeness error estimate based on the differences in modelled concentrations in neighboring gridcells (Bergamaschi et al., 2005). This yields observation error varying from 3 to several tens of ppb.

In the LMDz-SACS system, measurements are thinned so that only one measurement per grid cell per dynamical time step ( $30 \mathrm{~min}$ ) is kept. Moreover, after comparison with the prior forward simulation, measurements for which the matching simulated concentration is out of a range of $3 \sigma$ (see below for the specification of the error) were not used 
as constraints for the inversion. The observations of MCF concentrations are measurements made by NOAA/GMD and AGAGE surface networks (Montzka et al., 2000; Conway et al., 1994; Prinn et al., 2000). From 2003 to 2005, 10965 observations of MCF and 17926 observations of $\mathrm{CH}_{4}$ are used for the inversion. The observation errors are assumed not being correlated between stations. Assuming that the synoptic variability is an approximation of the transport errors, we used values of variances from Prinn et al. (2005) or from the NOAA (depending on the station); when no such data was available for a station, the uncertainties associated with the measurements were used, with a minimum threshold of $\pm 1.2 \mathrm{ppt}$ for $\mathrm{MCF}$ and $\pm 3 \mathrm{ppb}$ for $\mathrm{CH}_{4}$ (Pison et al., 2009). In this system, MCF observations are additionally assimilated in order to constrain OH. From 2003 to 2005, observation errors vary from 1.2 to 8 ppt for MCF and from 3 to $67.7 \mathrm{ppb}$ for $\mathrm{CH}_{4}$.

\section{B3 SCIAMACHY satellite observations}

SCIAMACHY $\mathrm{CH}_{4}$ retrievals of total columns with individual averaging kernels and prior vertical profiles have been provided by C. Frankenberg (SRON) throughout the HYMN project (Frankenberg et al., 2005, 2006, 2008). In both systems, column-average concentrations are assimilated. The measurement error is set at $2 \%$ of the value of the observation (Frankenberg et al., 2006). The selection criteria provided with the data include solar zenithal angles less than 70 and a simple cloud filter plus other selection criteria to eliminate back-scan pixels, poor fits of $\mathrm{RMS}$ of $\mathrm{CH}_{4}$ or $\mathrm{CO}$ microwindows and ensure minimal signal and number of pixels for the fit. In the TM5-4Dvar system, observations are averaged over $1^{\circ} \times 1^{\circ}$ grid boxes and three-hour assimilation windows before being compared to the modelled concentrations. An error of $1.5 \%$ is assumed (see also Bergamaschi et al., 2009; Meirink et al., 2008a), and between 2003 and 2005, a total of 749314 observations are assimilated. In the LMDz-SACS system the measurements selected according to the above criteria are averaged over each model grid cell during each time step and the observation error is taken to be the quadratic sum of the measurement error $(2 \%)$ and the chemistry-transport model error (arbritrary set to $10 \%$ ). A further sampling of the measurements for which the difference with the first-guess is less than one sigma finally had 923415 constraints for the inversion.
Acknowledgements. We would like to thank Catherine Prigent for providing the global inundation data set. This work was conducted within and supported by the EU-Project HYMN (Hydrogen, Methane, and Nitrous Oxide: Trend variability, budgets, and interactions with the biosphere; GOCE-037048). Additional financial support was provided by the Oeschger Centre for Climate Change Research and the Swiss National Science Foundation (Switzerland), the NERC funded programme QUEST - Quantifying and Understanding the Earth System (UK).

Edited by: T. Laurila

\section{References}

Aselmann, I. and Crutzen, P.: Global distribution of natural freshwater wetlands and rice paddies, their net primary productivity, seasonality and possible methane emissions, J. Atmos. Chem., 8, 307-358, 1989.

Bergamaschi, P., Krol, M., Dentener, F., Vermeulen, A., Meinhardt, F., Graul, R., Ramonet, M., Peters, W., and Dlugokencky, E. J.: Inverse modelling of national and European $\mathrm{CH}_{4}$ emissions using the atmospheric zoom model TM5, Atmos. Chem. Phys., 5, 2431-2460, doi:10.5194/acp-5-2431-2005, 2005.

Bergamaschi, P., Frankenberg, C., Meirink, J. F., Krol, M., Dentener, F., Wagner, T., Platt, U., Kaplan, J. O., Koerner, S., Heimann, M., Dlugokencky, E. J., and Goede, A.: Satellite chartography of atmospheric methane from SCIAMACHYon board ENVISAT: 2. Evaluation based on inverse model simulations, J. Geophys. Res., 112, D02304, doi:10.1029/2006JD007268, 2007.

Bergamaschi, P., Frankenberg, C., Meirink, J. F., Krol, M., Villani, M. G., Houweling, S., Dentener, F., Dlugokencky, E. J., Miller, J. B., Gatti, L. V., Engel, A., and Levin, I.: Inverse modeling of global and regional $\mathrm{CH}_{4}$ emissions using SCIAMACHY satellite retrievals, J. Geophys. Res., 114, D22301, doi:10.1029/2009JD012287, 2009.

Bloom, A. A., Palmer, P. I., Fraser, A., Reay, D. S., and Frankenberg, C.: Large-scale controls of methanogenesis inferred from methane and gravity spaceborne data, Science, 327, 322-325, doi:10.1126/science.1175176, 2010.

Bousquet, P., Hauglustaine, D. A., Peylin, P., Carouge, C., and Ciais, P.: Two decades of $\mathrm{OH}$ variability as inferred by an inversion of atmospheric transport and chemistry of methyl chloroform, Atmos. Chem. Phys., 5, 2635-2656, doi:10.5194/acp-52635-2005, 2005.

Bousquet, P., Ciais, P., Miller, J. B., Dlugokencky, E. J., Hauglustaine, D. A., Prigent, C., Van der Werf, G. R., Peylin, P., Brunke, E. G., Carouge, C., Langenfelds, R. L., Lathiere, J., Papa, F., Ramonet, M., Schmidt, M., Steele, L. P., Tyler, S. C., and White, J.: Contribution of anthropogenic and natural sources to atmospheric methane variability, Nature, 443, 439-443, doi:10.1038/nature05132, 2006.

Carmo, J. B. d., Keller, M., Dias, J. D., Camargo, P. B. d., and Crill, P.: A source of methane from upland forests in the Brazilian Amazon, Geophys. Res. Lett., 33, doi:10.1029/2005GL025436, 2006. 
Chen, Y.-H. and Prinn, R. G.: Estimation of atmospheric methane emissions between 1996 and 2001 using a three-dimensional global chemical transport model, J. Geophys. Res., 111, D10307, doi:10.1029/2005JD006058, 2006.

Chevallier, F., Fisher, M., Peylin, P., Serrar, S., Bousquet, P., Breon, F., Chedin, A., and Ciais, P.: Inferring $\mathrm{CO}_{2}$ sources and sinks from satellite observations: method and application to TOVS data, J. Geophys. Res., 110, D24309, doi:10.1029/2005JD006390, 2005.

Christensen, T., Prentice, I., Kaplan, J., Haxeltine, A., and Sitch, S.: Methane flux from northern wetlands and tundra - An ecosystem source modelling approach, Tellus B, 48, 652-661, 1996.

Conway, T., Tans, P., Waterman, L., and Thoning, K.: Evidence for interannual variability of the carbon cycle from the National Oceanic And Atmospheric Administration Climate Monitoring and Diagnostics Laboratory Global Air Sampling Network, J. Geophys. Res., 99, 22831-22855, 1994.

Curry, C. L.: Modeling the soil consumption of atmospheric methane at the global scale, Global Biogeochem. Cy., 21, GB4012-1-15, doi:10.1029/2006GB002818, 2007.

Dalsøren, S. B., Isaksen, I. S. A., Li, L., and Richter, A.: Effect of emission changes in Southeast Asia on global hydroxyl and methane lifetime, Tellus B, 61, 588-601, doi:10.1111/j.16000889.2009.00429.x, 2009.

Denman, K. L., Brasseur, G., Chidthaisong, A., Ciais, P., Cox, P., Dickinson, R. E., Hauglustaine, D., Heinze, C., Holland, E., Jacob, D., Lohmann, U., Ramachandran, S., da Silva Dias, P. L., Wofsy, S. C., and Zhang, X.: Chapter 7: Couplings between changes in the climate system and biogeochemistry, in: Climate Change 2007: The Physical Science Basis. Contribution of Working Group I to the Fourth Assessment Report of the Intergovernmental Panel on Climate Change, edited by: Solomon, S., Qin, D., Manning, M., Chen, Z., Marquis, M., Averyt, K., Tignor, M., and Miller, H., Cambridge University Press, UK and New York, NY, USA, 2007.

Dlugokencky, E., Myers, R., Lang, P., Masarie, K., Crotwell, A., Thoning, K., Hall, B., Elkins, J., and Steele, L.: Conversion of NOAA atmospheric dry air $\mathrm{CH}_{4}$ mole fractions to a gravimetrically prepared standard scale, J. Geophys. Res., 110, D18306, doi:10.1029/2005JD006035, 2005.

Dlugokencky, E., Bruhwiler, L., White, J., Emmons, L., Novelli, P., Montzka, S., Masarie, K., Lang, P., Crotwell, A., Miller, J., and Gatti, L.: Observational constraints on recent increases in the atmospheric $\mathrm{CH}_{4}$ burden, Geophys. Res. Lett., 36, L18803, 2009.

EC-JRC/PBL: European Commission - Joint Research Centre (JRC)/Netherlands Environmental Assessment Agency (PBL), Emission Database for Global Atmospheric Research (EDGAR), release version 3.2, available at: http://edgar.jrc.ec.europa.eu, last access: 1 August 2009, 2009.

Etiope, G., Lassey, K. R., Klusman, R. W., and Boschi, E.: Reappraisal of the fossil methane budget and related emission from geologic sources, Geophys. Res. Lett., 35, L09307, doi:10.1029/2008GL033623, 2008.

Fang, C. and Moncrieff, J.: A model for soil $\mathrm{CO}_{2}$ production and transport 1: model development, Agr. Forest Meterol., 95, 225236, 1999 .

Folberth, G., Hauglustaine, D., Ciais, P., and Lathiere, J.: On the role of atmospheric chemistry in the global $\mathrm{CO}_{2}$ budget, Geophys. Res. Lett., 32, L08801, doi:10.1029/2004GL021812, 2005.
Forster, P., Ramaswamy, V., Artaxo, P., Berntsen, T., Betts, R., Fahey, D., Haywood, J., Lean, J., Lowe, D., Myhre, G., Nganga, J., Prinn, R., Raga, G., Schulz, M., and Dorland, R. V.: Chapter 2: Changes in atmospheric constituents and in radiative forcing, in: Climate Change 2007: The Physical Science Basis. Contribution of Working Group I to the Fourth Assessment Report of the Intergovernmental Panel on Climate Change, edited by: Solomon, S., Qin, D., Manning, M., Chen, Z., Marquis, M., Averyt, K., Tignor, M., and Miller, H., Cambridge University Press, UK and New York, NY, USA, 2007.

Frankenberg, C., Meirink, J., van Weele, M., Platt, U., and Wagner, T.: Assessing methane emissions from global space-borne observations, Science, 308, 1010-1014, doi:10.1126/science.1106644, 2005.

Frankenberg, C., Meirink, J., Bergamaschi, P., Goede, A., Heimann, M., Korner, S., Platt, U., van Weele, M., and Wagner, T.: Satellite chartography of atmospheric methane from SCIAMACHY on board ENVISAT: analysis of the years 2003 and 2004, J. Geophys. Res., 111, D07303, doi:10.1029/2005JD006235, 2006.

Frankenberg, C., Bergamaschi, P., Butz, A., Houweling, S., Meirink, J. F., Notholt, J., Petersen, A. K., Schrijver, H., Warneke, T., and Aben, I.: Tropical methane emissions: a revised view from SCIAMACHY onboard ENVISAT, Geophys. Res. Lett., 35, L15811, doi:10.1029/2008GL034300, 2008.

Gauci, V., Cowing, D. J. G., Hornibrook, E. R. C., Davis, J. M., and Dise, N. B.: Woody stem methane emission in mature wetland alder trees, Atmospheric Environment, 44, 2157-2160, doi:10.1016/j.atmosenv.2010.02.034, 2010.

Gerten, D., Schaphoff, S., Haberlandt, U., Lucht, W., and Sitch, S.: Terrestrial vegetation and water balance - hydrological evaluation of a dynamic global vegetation model, J. Hydrol., 286, 249270, doi:10.1016/j.jhydrol.2003.09.029, 2004.

Gilbert, J. and Lemaréchal, C.: Some numerical experiments with variable-storage quasi-newton algorithms, Math. Program., 45, 407-435, 1989.

Global Soil Data Task Group: Global gridded surfaces of selected soil characteristics (international geosphere-biosphere programme - data and information system, IGBP-DIS), doi:10.3334/ORNLDAAC/569, available at: http://www.daac. ornl.gov, last access: 1 August 2009, 2000.

GLOBALVIEW- $\mathrm{CH}_{4}$ : Cooperative atmospheric data integration project - methane, available at: ftp://ftp.cmdl.noaa.gov/ccg/ch4/ GLOBALVIEW/, last access: 1 January 2010, 2009.

Gurney, K., Law, R., Denning, A., Rayner, P., Baker, D., Bousquet, P., Bruhwiler, L., Chen, Y., Ciais, P., Fan, S., Fung, I., Gloor, M., Heimann, M., Higuchi, K., John, J., Maki, T., Maksyutov, S., Masarie, K., Peylin, P., Prather, M., Pak, B., Randerson, J., Sarmiento, J., Taguchi, S., Takahashi, T., and Yuen, C.: Towards robust regional estimates of $\mathrm{CO}_{2}$ sources and sinks using atmospheric transport models, Nature, 415, 626-630, 2002.

Hadi, A., Inubushi, K., Furukawa, Y., Purnomo, E., Rasmadi, M., and Tsuruta, H.: Greenhouse gas emissions from tropical peatlands of Kalimantan,Indonesia, Nutrient Cycling in Agroecosystems, 71, 73-80, doi:10.1007/s10705-004-0380-2, 2005.

Hauglustaine, D., Hourdin, F., Jourdain, L., Filiberti, M., Walters, S., Lamarque, J., and Holland, E.: Interactive chemistry in the Laboratoire de Météorologie Dynamique gen- 
eral circulation model: Description and background tropospheric chemistry evaluation, J. Geophys. Res., 109, D04314, doi:10.1029/2003JD003957, 2004.

Hourdin, F., Musat, I., Bony, S., Braconnot, P., Codron, F., Dufresne, J.-L., Fairhead, L., Filiberti, M.-A., Friedlingstein, P., Grandpeix, J.-Y., Krinner, G., LeVan, P., Li, Z.-X., and Lott, F.: The LMDZ4 general circulation model: climate performance and sensitivity to parametrized physics with emphasis on tropical convection, Clim. Dynam., 27, 787-813, doi:10.1007/s00382006-0158-0, 2006.

Houweling, S., Kaminski, T., Dentener, F., Lelieveld, J., and Heimann, M.: Inverse modeling of methane sources and sinks using the adjoint of a global transport model, J. Geophys. Res., 104, 26137-26160, 1999.

Inubushi, K., Furukawa, Y., Hadi, A., Purnomo, E., and Tsuruta, H.: Seasonal changes of $\mathrm{CO}_{2}, \mathrm{CH}_{4}$ and $\mathrm{N}_{2} \mathrm{O}$ fluxes in relation to land-use change in tropical peatlands located in coastal area of South Kalimantan, Chemosphere, 52, 603 - 608, doi:10.1016/S0045-6535(03)00242-X, Biogeochemical Processes and Cycling of Elements in the Environment, 2003.

Ishizuka, $\mathrm{S}$.: An intensive field study on $\mathrm{CO}_{2}, \mathrm{CH}_{4}$, and $\mathrm{N}_{2} \mathrm{O}$ emissions from soils at four land-use types in Sumatra, Indonesia, Global Biogeochem. Cycles, 16, doi:10.1029/2001GB001614, 2002.

Joos, F., Gerber, S., Prentice, I. C., Otto-Bliesner, B. L., and Valdes, P. J.: Transient simulations of Holocene atmospheric carbon dioxide and terrestrial carbon since the Last Glacial Maximum, Global Biogeochem. Cy., 18, 1-18, doi:10.1029/2003GB002156, 2004.

Kammann, C., Grünhage, L., H, J., and G, W.: Methane fluxes from differentially managed grassland study plots: the important role of $\mathrm{CH}_{4}$ oxidation in grassland with a high potential for $\mathrm{CH}_{4}$ production, Environmental Pollution, 115, 261-273, 2001.

Kaplan, J. O.: Wetlands at the Last Glacial Maximum: distribution and methane emissions, Geophys. Res. Lett., 29, 1079, doi:10.1029/2001GL013366, 2002.

Keppler, F., Hamilton, J. T. G., Brass, M., and Rockmann, T.: Methane emissions from terrestrial plants under aerobic conditions, NATURE, 439, 187-191, doi:10.1038/nature04420, 2006.

Kettunen, A.: Connecting methane fluxes to vegetation cover and water table fluctuations at microsite level: a modeling study, Global Biogeochem. Cy., 17, 1051, doi:10.1029/2002GB001958, 2003.

Krol, M., Houweling, S., Bregman, B., van den Broek, M., Segers, A., van Velthoven, P., Peters, W., Dentener, F., and Bergamaschi, P.: The two-way nested global chemistry-transport zoom model TM5: algorithm and applications, Atmos. Chem. Phys., 5, 417-432, doi:10.5194/acp-5-417-2005, 2005.

Lambert, G. and Schmidt, S.: Reevaluation of the oceanic flux of methane - uncertainties and long-term variations, Chemosphere, 26, 579-589, 1993.

Leff, B., Ramankutty, N., and Foley, J.: Geographic distribution of major crops across the world, Global Biogeochem. Cy., 18, GB1009, doi:10.1029/2003GB002108, 2004.

Lloyd, J. and Taylor, J.: On the temperature-dependence of soil respiration, Funct. Ecol., 8, 315-323, 1994.

Martinson, G. O., Werner, F. A., Scherber, C., Conrad, R., Corre, M. D., Flessa, H., Wolf, K., Klose, M., Gradstein, S. R., and Veldkamp, E.: Methane emissions from tank bromeli- ads in neotropical forests, Nature Geoscience, 3, 766-769, doi:10.1038/NGEO980, 2010.

Matthews, E. and Fung, I.: Methane emissions from natural wetlands: global distribution, area and environmental characteristics of sources, Global Biogeochem. Cy., 1, 61-86, 1987.

Meirink, J. F., Bergamaschi, P., Frankenberg, C., d'Amelio, M. T. S., Dlugokencky, E. J., Gatti, L. V., Houweling, S., Miller, J. B., Roeckmann, T., Villani, M. G., and Krol, M. C.: Four-dimensional variational data assimilation for inverse modeling of atmospheric methane emissions: analysis of SCIAMACHY observations, J. Geophys. Res., 113, D17301, doi:10.1029/2007JD009740, 2008a.

Meirink, J. F., Bergamaschi, P., and Krol, M. C.: Fourdimensional variational data assimilation for inverse modelling of atmospheric methane emissions: method and comparison with synthesis inversion, Atmos. Chem. Phys., 8, 6341-6353, doi:10.5194/acp-8-6341-2008, 2008b.

Melling, L., Hatano, R., and Goh, K. J.: Methane fluxes from three ecosystems in tropical peatland of Sarawak, Malaysia, Soil Biology and Biochemistry, 37, 1445 - 1453, doi:10.1016/j.soilbio.2005.01.001, 2005.

Mitchell, T. D. and Jones, P. D.: An improved method of constructing a database of monthly climate observations and associated high-resolution grids, Int. J. Climatol., 25, 693-712, doi:10.1002/joc.1181, available at: http://badc.nerc.ac.uk/data/ cru/, last access: 1 August 2009, 2005.

Montzka, S., Spivakovsky, C., Butler, J., Elkins, J., Lock, L., and Mondeel, D.: New observational constraints for atmospheric hydroxyl on global and hemispheric scales, Science, 288, 500-503, 2000.

Montzka, S. A., Krol, M., Dlugokencky, E., Hall, B., Joeckel, P., and Lelieveld, J.: Small Interannual Variability of Global Atmospheric Hydroxyl, Science, 331, doi:10.1126/science.1197640, 2011.

Neef, L., van Weele, M., and van Velthoven, P. F. J.: Optimal estimation of the present-day global methane budget, Global Biogeochem. Cy., 24, GB4024, doi:10.1029/2009GB003661, 2010.

Otter, L. and Scholes, M.: Methane sources and sinks in a periodically flooded South African savanna, Global Biogeochem. Cy., 14, 97-111, 2000.

Page, S., Wüst, R., Weiss, D., Rieley, J., Shotyk, W., and Limin, S.: A record of Late Pleistocene and Holocene carbon accumulation and climate change from an equatorial peat bog (Kalimantan, Indonesia): implications for past, present and future carbon dynamics, Symposium on Late Quaternary Ecosystem Dynamics and Carbon Cycling in the Tropics held at the 16th INQUA Congress, Reno, NV, 23-30 July 2003, J. Quaternary Sci., 19, 625-635, doi:10.1002/jqs.884, 2004.

Peichl, M., Arain, M. A., Ullah, S., and Moore, T. R.: Carbon dioxide, methane, and nitrous oxide exchanges in an age-sequence of temperate pine forests, Global Change Biology, 16, 2198-2212, doi:10.1111/j.1365-2486.2009.02066.x, 2010.

Pison, I., Bousquet, P., Chevallier, F., Szopa, S., and Hauglustaine, D.: Multi-species inversion of $\mathrm{CH}_{4}, \mathrm{CO}$ and $\mathrm{H}_{2}$ emissions from surface measurements, Atmos. Chem. Phys., 9, 5281-5297, doi:10.5194/acp-9-5281-2009, 2009.

Prigent, C., Papa, F., Aires, F., Rossow, W. B., and Matthews, E.: Global inundation dynamics inferred from multiple satellite observations, 1993-2000, J. Geophys. Res., 112, D12107, 
doi:10.1029/2006JD007847, 2007.

Prinn, R., Weiss, R., Fraser, P., Simmonds, P., Cunnold, D., Alyea, F., O'Doherty, S., Salameh, P., Miller, B., Huang, J., Wang, R., Hartley, D., Harth, C., Steele, L., Sturrock, G., Midgley, P., and McCulloch, A.: A history of chemically and radiatively important gases in air deduced from ALE/GAGE/AGAGE, J. Geophys. Res., 105, 17751-17792, 2000.

Prinn, R., Huang, J., Weiss, R., Cunnold, D., Fraser, P., Simmonds, P., McCulloch, A., Harth, C., Reimann, S., Salameh, P., O'Doherty, S., Wang, R., Porter, L., Miller, B., and Krummel, P.: Evidence for variability of atmospheric hydroxyl radicals over the past quarter century, Geophys. Res. Lett., 32, L07809, doi:10.1029/2004GL022228, 2005.

Rice, A. L., Butenhoff, C. L., Shearer, M. J., Teama, D., Rosenstiel, T. N., and Khalil, M. A. K.: Emissions of anaerobically produced methane by trees, Geophysical Research Letters, 37, doi:10.1029/2009GL041565, 2010.

Ridgwell, A., Marshall, S., and Gregson, K.: Consumption of atmospheric methane by soils: a process-based model, Global Biogeochem. Cy., 13, 59-70, 1999.

Rigby, M., Prinn, R. G., Fraser, P. J., Simmonds, P. G., Langenfelds, R. L., Huang, J., Cunnold, D. M., Steele, L. P., Krummel, P. B., Weiss, R. F., O'Doherty, S., Salameh, P. K., Wang, H. J., Harth, C. M., Muehle, J., and Porter, L. W.: Renewed growth of atmospheric methane, Geophys. Res. Lett., 35, L22805, doi:10.1029/2008GL036037, 2008.

Ringeval, B., de Noblet-Ducoudre, N., Ciais, P., Bousquet, P., Prigent, C., Papa, F., and Rossow, W. B.: An attempt to quantify the impact of changes in wetland extent on methane emissions on the seasonal and interannual time scales, Global Biogeochem. Cy., 24, GB2003, doi:10.1029/2008GB003354, 2010.

Robinson, S. and Moore, T.: The influence of permafrost and fire upon carbon accumulation in high boreal peatlands, Northwest Territories, Canada, Arct. Antarct. Alp. Res., 32, 155-166, 2000.

Rouse, W., Douglas, M., Hecky, R., Hershey, A., Kling, G., Lesack, L., Marsh, P., McDonald, M., Nicholson, B., Roulet, N., and Smol, J.: Effects of climate change on the freshwaters of arctic and subarctic North America, Hydrological Processes, 11, 873902, Symposium on Regional Assessment of Freshwater Ecosystems and Climate Change in North America, LEESBURG, VA, OCT 24-26, 1994, 1997.

Sanderson, M.: Biomass of termites and their emissions of methane and carbon dioxide: a global database, Global Biogeochem. Cy., 10, 543-557, 1996.

Sanhueza, E. and Donoso, L.: Methane emission from tropical savanna Trachypogon sp. grasses, Atmos. Chem. Phys., 6, 53155319, doi:10.5194/acp-6-5315-2006, 2006.

Semeniuk, V. and Semeniuk, C. A.: A geomorphic approach to global classification for natural inland wetlands and rationalization of the system used by the Ramsar Convention - a discussion, Wetl. Ecol. Manag., 5, 145-158, 1997.

Sheng, Y., Smith, L., MacDonald, G., Kremenetski, K., Frey, K., Velichko, A., Lee, M., Beilman, D., and Dubinin, P.: A high-resolution GIS-based inventory of the West Siberian peat carbon pool, Global Biogeochem. Cy., 18, GB3004, doi:10.1029/2003GB002190, 2004.

Simona, C., Ariangelo, D. P. R., John, G., Nina, N., Ruben, M., and Jos, S. J.: Nitrous oxide and methane fluxes from soils of the Orinoco savanna under different land uses, Global Change Bi- ology, 10, 1947-1960, doi:10.1111/j.1365-2486.2004.00871.x, 2004.

Sitch, S., Smith, B., Prentice, I. C., Arneth, A., Bondeau, A., Cramer, W., Kaplan, J. O., Levis, S., Lucht, W., Sykes, M. T., Thonicke, K., and Venevsky, S.: Evaluation of ecosystem dynamics, plant geography and terrestrial carbon cycling in the LPJ dynamic global vegetation model, Glob. Change Biol., 9, 161$185,2003$.

Sitch, S., Huntingford, C., Gedney, N., Levy, P. E., Lomas, M., Piao, S. L., Betts, R., Ciais, P., Cox, P., Friedlingstein, P., Jones, C. D., Prentice, I. C., and Woodward, F. I.: Evaluation of the terrestrial carbon cycle, future plant geography and climatecarbon cycle feedbacks using five dynamic global vegetation models (DGVMs), Glob. Change Biol., 14, 2015-2039, 2008.

Spahni, R., Wania, R., Neef, L., van Weele, M., Pison, I., Bousquet, P., Frankenberg, C., Foster, P. N., Joos, F., Prentice, I. C., and van Velthoven, P.: Constraining global methane emissions and uptake by ecosystems, Biogeosciences Discussions, 8, 221-272, doi:10.5194/bgd-8-221-2011, 2011.

Stevenson, D., Dentener, F., Schultz, M., Ellingsen, K., van Noije, T., Wild, O., Zeng, G., Amann, M., Atherton, C., Bell, N., Bergmann, D., Bey, I., Butler, T., Cofala, J., Collins, W., Derwent, R., Doherty, R., Drevet, J., Eskes, H., Fiore, A., Gauss, M., Hauglustaine, D., Horowitz, L., Isaksen, I., Krol, M., Lamarque, J.-F., Lawrence, M., Montanaro, V., Muller, J.-F., Pitari, G., Prather, M., Pyle, J., Rast, S., Rodriguez, J., Sanderson, M., Savage, N., Shindell, D., Strahan, S., Sudo, K., and Szopa, S.: Multimodel ensemble simulations of present-day and near-future tropospheric ozone, J. Geophys. Res., 111, D08301, doi:10.1029/2005JD006338, 2006.

Teh, Y. A., Silver, W. L., and Conrad, M. E.: Oxygen effects on methane production and oxidation in humid tropical forest soils, Global Change Biology, 11, 1283-1297, doi:10.1111/j.13652486.2005.00983.x, 2005.

van Weele, M. and van Velthoven, P. F. J.: Multi-year budget analysis of recent changes in global atmospheric methane levels, submitted to J. Integr. Environ. Sci., 2010.

Viovy, N. and Ciais, P.: CRUNCEP data set for 1901-2008, available at: http://dods.extra.cea.fr/data/p529viov/cruncep/readme. htm, last access: 1 July 2010, 2009.

Walter, B. P., Heimann, M., and Matthews, E.: Modeling modern methane emissions from natural wetlands 1 . model description and results, J. Geophys. Res., 106, 34189-34206, 2001 a.

Walter, B. P., Heimann, M., and Matthews, E.: Modeling modern methane emissions from natural wetlands 2 . interannual variations 1982-1993, J. Geophys. Res., 106, 34207-34219, 2001 b.

Wania, R., Ross, I., and Prentice, I. C.: Integrating peatlands and permafrost into a dynamic global vegetation model: 1 . evaluation and sensitivity of physical land surface processes, Global Biogeochem. Cy., 23, GB3014, doi:10.1029/2008GB003412, 2009a.

Wania, R., Ross, I., and Prentice, I. C.: Integrating peatlands and permafrost into a dynamic global vegetation model: 2. evaluation and sensitivity of vegetation and carbon cycle processes, Global Biogeochem. Cy., 23, GB3015, doi:10.1029/2008GB003413, 2009b.

Wania, R., Ross, I., and Prentice, I. C.: Implementation and evaluation of a new methane model within a dynamic global vegetation model: LPJ-WHyMe v1.3, Geosci. Model Dev. Discuss., 3, 1- 
59, doi:10.5194/gmdd-3-1-2010, 2010a.

Wania, R., Ross, I., and Prentice, I. C.: Implementation and evaluation of a new methane model within a dynamic global vegetation model: LPJ-WHyMe v1.3.1, Geosci. Model Dev., 3, 565-584, doi:10.5194/gmd-3-565-2010, 2010 b.

Werner, C., Kiese, R., and Butterbach-Bahl, K.: Soil-atmosphere exchange of $\mathrm{N}_{2} \mathrm{O}, \mathrm{CH}_{4}$, and $\mathrm{CO}_{2}$ and controlling environmental factors for tropical rain forest sites in western Kenya, J. Geophys. Res., 112, doi:10.1029/2006JD007388, 2007.

World Data Centre for Greenhouse Gases: WDCGG, available at: http://gaw.kishou.go.jp/wdcgg/, last access: 1 August 2009, 2008.

Yan, X., Akiyama, H., Yagi, K., and Akimoto, H.: Global estimations of the inventory and mitigation potential of methane emissions from rice cultivation conducted using the 2006 intergovernmental panel on climate change guidelines, Global Biogeochem. Cy., 23, GB2002, doi:10.1029/2008GB003299, 2009.
Yan, Y., Sha, L., Cao, M., Zheng, Z., Tang, J., Wang, Y., Zhang, Y., Wang, R., Liu, G., Wang, Y., and Sun, Y.: Fluxes of $\mathrm{CH}_{4}$ and $\mathrm{N}_{2} \mathrm{O}$ from soil under a tropical seasonal rain forest in Xishuangbanna, Southwest China, J. Environ. Sci.-China, 20, 207-215, 2008.

Zhuang, Q., Melillo, J., Kicklighter, D., Prinn, R., McGuire, A., Steudler, P., Felzer, B., and Hu, S.: Methane fluxes between terrestrial ecosystems and the atmosphere at northern high latitudes during the past century: a retrospective analysis with a process-based biogeochemistry model, Global Biogeochem. Cy., 18, GB3010, doi:10.1029/2004GB002239, 2004. 